\title{
A multi-criteria sustainability assessment for biodiesel and liquefied natural gas as alternative fuels in transport systems
}

\author{
Jose Luis Osorio-Tejada \\ CIRCE - University of Zaragoza \\ E-mail: jlosorio@unizar.es \\ Eva Llera-Sastresa \\ Department of Mechanical Engineering - CIRCE - University of Zaragoza \\ E-mail: ellera@unizar.es \\ Sabina Scarpellini \\ Department of Accounting and Finance - CIRCE - University of Zaragoza \\ E-mail: sabina@unizar.es
}

Keywords: Liquefied natural gas (LNG); freight transport; alternative fuel; analytic hierarchy process (AHP); multi-criteria decision making (MCDM); hydrotreated vegetable oil (HVO)

\begin{abstract}
The incorporation of clean-fuel technologies has become essential for the sustainability of the transportation sector. Natural gas technology, especially the use of liquefied natural gas (LNG), has become a possible alternative to diesel oil in freight transport because of its acceptable autonomy and low fuel prices. For the introduction of this alternative fuel, freight companies need tools that allow them to perform an integrated assessment of relevant aspects related to environment, economy and social responsibility. This paper introduces a multi-criteria based methodology that integrates the key factors involved in the transport system: vehicles, infrastructure and fuels, and consideration of the three pillars of sustainability, as well as the reliability of technology, legislation and market issues. In particular, a case study for the impact assessment of LNG in comparison to hydrotreated vegetable oil (HVO) and diesel oil as regular long-haul freight transport fuels in Spain was developed. The information for the comparison process was obtained from peer-reviewed articles and reports from international and Spanish institutions, while the primary data was obtained through semi-structured in-depth interviews to the different stakeholders. A weighted sustainability index for each alternative was developed to integrate the data obtained through the analytic hierarchy process. The results indicate that LNG trucks would be an attractive option compared to diesel oil and HVO, provided that decision-makers give significant weight to social and environmental criteria, and that the government guarantees a legislative security to maintain the low taxes on natural gas. Integration of stakeholders allows making the most appropriate decision according to the objectives of the company. The application of the proposed methodology shows consistent results, which should ensure the success of a long-term alternative in the dynamic market for transportation fuels.
\end{abstract}


Osorio-Tejada, J., Llera-Sastresa, E., Scarpellini, S., 2017. A multi-criteria sustainability assessment for biodiesel and liquefied natural gas as alternative fuels in transport systems. Journal of Natural Gas Science and Engineering, 42, pp. 169-186. PRE-PRINT version of: $\underline{\mathrm{dx} . \text { doi.org/10.1016/j.jngse.2017.02.046 }}$

\section{Introduction}

Governments have been promoting the use of alternative fuels to reduce environmental pollution and oil dependence, especially after the 1973 petroleum crisis. At the beginning of this century, the European Union (EU) set the objective of replacing $20 \%$ of conventional fuels by 2020 through the introduction of liquid biofuels in the short term, natural gas (NG) in the medium and long term and hydrogen in the distant long term (European Commission, 2000). In addition, it was expected that biofuels shared at least $6 \%$ of the fuels used in road transport in 2010 (Commission of the European Communities, 2001). However, biofuels only shared $4.4 \%$ by 2010 (European Commission, 2013), which was mainly the result of socioeconomic problems generated in Europe and in developing countries by the production of feedstocks, such as an increase in food prices and land use competition (EEGFTF, 2011). For that reason, the European Commission (2013) recommended different alternative fuels based on the maturity of the technologies for each application, such as electricity, compressed natural gas $(\mathrm{CNG})$ and hydrogen, for urban use vehicles and liquefied natural gas (LNG) for long-haul transport.

Some of the reasons for governments to encourage the use of NG in vehicles are the benefits of reducing local air pollution, resources availability, the existence of distribution infrastructure and relatively lower prices than petroleum fuels (Yeh, 2007). NG has been widely and profitably applied in compressed form in many countries mainly in urban vehicles. CNG has only been popular in urban vehicles due to the low energy density of gaseous NG, which gives low autonomy, whereas by storing NG in liquid form, LNG vehicles can increase their autonomy by up to $1100 \mathrm{~km}$ (DENA, 2014). Additionally, there are many key facts that motivate the adoption of LNG technology for freight transport. Recent studies suggested that LNG use in heavy duty vehicles (HDV) has the potential to reduce environmental impacts and noise in cities, in addition to the maturity of the technology, energy resource availability and clear interest of the EU in supporting the LNG adoption (Osorio-Tejada et al., 2015). However, since the introduction of NG technologies, legislators and companies require compressive tools to perform an integrated assessment of all relevant aspects related to environment, economy and their social responsibility, as well as the reliability of technology, legislation and market issues.

Although corporate environmental responsibility and sustainable development have been discussed since the 80s (UNCED, 1992), companies in the transport sector have not been concerned with taking initiative to optimize operations and reduce environmental impacts. One of the reasons for this is that the regulations derived from the Kyoto Protocol (UNFCCC, 1998) to combat climate change were only focused on reducing emissions of greenhouse gases (GHG) in the industrial and energy sectors, which were included in the Emissions Trading Scheme (ETS) in Directive 2003/87/CE (European Parliament And The Council Of The European Union, 2003).

The growth in the share of freight transport by road, which carries $74.9 \%$ of the tons-kilometer (tkm) inside the EU (European Commission, 2014), is a concern that has increased in importance. The transport sector in the EU released 24.4\% of the total GHG in 2013 (European Environment Agency, 2015a), and road transport contributed to $94.6 \%$ of the total emissions (European Environment Agency, 2015b). Although regulations, such as the European air pollution standards (Euro I-VI) (European Parliament And The Council Of The European Union, 2009a), set limits on vehicle emissions of carbon monoxide (CO), volatile organic compounds (VOCs), nitrogen oxides (NOx) and particulate matter (PM), regulations to control the emissions of carbon dioxide $\left(\mathrm{CO}_{2}\right)$ in $\mathrm{HDV}$ have not been established.

Since the inclusion of diffuse sectors in the ETS in 2009 (European Parliament And The Council Of The European Union, 2009b), the calculation and reporting of GHG by freight companies has been promoted. This scenario has also encouraged companies to adopt strategies to differentiate themselves from their competitors by reducing their contribution to the carbon footprint of transported products, which saves fuel and helps to achieve a more sustainable freight transport subsector, at least environmentally.

The progress made by manufacturers to reduce fuel consumption in HDV, such as the use of body aerodynamics, lightweight materials, low viscosity lubricants or wide-base single tires, has contributed to 
Osorio-Tejada, J., Llera-Sastresa, E., Scarpellini, S., 2017. A multi-criteria sustainability assessment for biodiesel and liquefied natural gas as alternative fuels in transport systems. Journal of Natural Gas Science and Engineering, 42, pp. 169-186. PRE-PRINT version of: $\underline{\mathrm{dx} . \text { doi.org/10.1016/j.jngse.2017.02.046 }}$

reduce the amount of $\mathrm{CO}_{2}$ emissions per $\mathrm{km}$ traveled. However, efforts to meet the European air quality standards by modifying engines and installing devices for the after-treatment of exhaust gases, such as exhaust gas recirculation valves and particulate filters to reduce NOx and PM emissions, respectively, have affected fuel efficiency (Akkermans and Leuven, 2014; Benajes et al., 2015; Dünnebeil and Lambrecht, 2012). In addition to improving the performance of these processes, the most appropriate measure to reduce the environmental impact of trucks is by using less polluting alternative fuels, which do not require excessive treatments of exhaust gases.

In Europe, public institutions and transport companies have been encouraged to develop carbon footprint reports and conduct inventories of energy consumption and emissions of road fleets. In addition, a large number of initiatives, methodologies, databases and commercial tools have been developed. According to the COFRET project (VTT, 2011), a total of 102 initiatives were reported by 2011. Currently, most of the available initiatives work based on the European standard EN-16258:2012 Methodology for calculation and declaration of energy consumption and GHG emissions in transport services (transport freight and passenger). This standard limits the reporting to the well-to-wheels (WTW) analysis, which only includes the fuel life cycle because the vehicle use phase is responsible for over $80 \%$ of the total GHG released by all of the transport system factors (vehicles, infrastructure and fuels) in their life cycles (Nahlik et al., 2016; Uson et al., 2011). Therefore, the WTW analysis neglects the impact of vehicle and infrastructure construction because these factors are considered to be minor or consist of a small proportion of the total GHG emissions. Nevertheless, considering emissions other than GHG, the contribution of vehicles and infrastructure to the life cycle is noteworthy. For example, PM emissions associated with road construction are three times higher than those emitted during the production and use of fuels (Facanha and Horvath, 2007). Similarly, if economic and social impacts were measured, these factors could represent a much greater weight, which should not be neglected.

In this regard, the introduction of alternative fuels generates consequences regarding the different factors of the transport system, and it is important for decision-making purposes to have a methodology that integrates the three pillars of sustainability by analyzing the economic, environmental and social impacts for each of these factors, as well market-related indicators, such as legislative issues, energy and infrastructure availability, which have been considered the main challenges to the adoption of alternative fuels (Jaffe et al., 2015).

In this paper, a systematic approach based on the study of the multidimensional impacts of transportation systems and the application of multi-criteria decision making (MCDM) to assess the sustainability of alternative fuels is presented. Section 2 introduces the theoretical framework of the MCDM methods for the evaluation of alternatives and considers different criteria and stakeholders to establish the advantages of using this type of methodology for decision-making in transportation. The methodology is presented in Section 3 and describes each step to conduct an appropriate selection based on a sustainability index. In Section 4, a case study for the introduction of HVO and LNG combustion technology in a private fleet for road freight transport in Spain is described. Subsequently, the results and study's conclusions are presented.

\section{Multidimensional impact assessment in the transport sector}

In practice, both private companies and public administrations usually apply financial, profitability and costbenefits analysis (CBA) for decision-making in the transport sector (Dodgson et al., 2009). These techniques assess alternatives in monetary terms of economic and some social and environmental aspects represented in external costs, such as air pollution, noise and accidents. However, monetizing many of these variables requires great expertise, time and training to conduct these studies properly. In addition, there are many other variables or indicators that are very difficult to compare by these methods.

In recent years, the use of life-cycle assessments (LCA) for the environmental analysis of projects in the transport sector has increased, mainly in the analysis of fuels (Borrion et al., 2012; Larson, 2006; Manik and 
Osorio-Tejada, J., Llera-Sastresa, E., Scarpellini, S., 2017. A multi-criteria sustainability assessment for biodiesel and liquefied natural gas as alternative fuels in transport systems. Journal of Natural Gas Science and Engineering, 42, pp. 169-186. PRE-PRINT version of: $\underline{\mathrm{dx} . \text { doi.org/10.1016/j.jngse.2017.02.046 }}$

Halog, 2012; Quinn and Davis, 2015; Shonnard et al., 2015; von Blottnitz and Curran, 2007; Wiloso et al., 2012) as well as roads (Carlson, 2011; Muench, 2010) and vehicles (CNH Industrial, 2014; MAN SE, 2014; Volvo AB, 2013). The main objective has been the estimation of GHG reductions to establish the possible income via the carbon market or subsidies from programs for climate change mitigation. Thus, after the calculation of the economic benefit of reducing the carbon footprint is incorporated into the financial analysis, the decision is based purely on the economic criterion.

Hence, to broaden the perspective of sustainability in all three of its dimensions (environmental, social and economic), which is known as Triple Bottom Line (Elkington, 1998) or the 3P's concept (People, Planet and Profit/Prosperity), methodologies have been created to integrate the environmental analysis from LCA with social life-cycle assessments (SLCA) and life cycle costing (LCC). Several authors have proposed integrating the 3P's into a single methodology called a life-cycle sustainability assessment (LCSA) (Andrews et al., 2009; Heijungs et al., 2010; Kloepffer, 2008; Weidema, 2006). However, due to difficulties of integrating these three types of LCA and their methodological differences, boundaries and scopes, functional units and other factors involving a comprehensive assessment, the development of a LCSA has not transcended theoretical discussions and isolated case studies.

Similarly, the development of life-cycle techniques for social and economic/financial aspects has not reached a consensus to become a unique and fully accepted methodology by the international community because ambiguities remain in their application, unlike the environmental LCA, which has been internationally recognized by standards, such as ISO 14040 (International organization for standardization, 2006). In the transport sector, three studies have been conducted under the SLCA framework to assess biofuels because of the concern for possible negative social impacts in developing countries that produce these resources (Blom and Solmar, 2009; Ekener-Petersen et al., 2014; Manik et al., 2013). Manik and colleagues, in addition to gather information from secondary sources, conducted fieldwork with stakeholders through interviews and surveys. However, in the two other studies, the authors stated that the reliability of the results was not fully satisfactory due to difficulties in finding relevant data and the impossibility of performing personal visits to the companies or interviews with the directly affected communities. For this reason, they concluded that there is a clear need for consistent databases for these social indicators, such as those available for environmental LCAs.

In the case of LCC, there are sufficient studies in the transport sector (Bhadury et al., 2006; Hackney and de Neufville, 2001; Schroeder and Majumdar, 2010; Shahraeeni et al., 2015), but most of them actually use the theory of total cost of ownership (TCO), which was defined in 1995 (Ellram, 1995) as a tool to calculate the actual cost of having a product or service from the point of view of the buyer or user. Two studies have come close to the LCC perspective by including external costs in their analyses (Goedecke, 2005; Li et al., 2014). In total, the gap is clear in terms of appropriate methodologies for social and economic assessments that permit hybridization with an environmental LCA to conduct a comprehensive analysis of the sustainability of freight transport.

Goh and Yang (2014) highlighted the importance of considering the social and environmental costs in an LCC, but their calculations and analyses lack clear methodologies. In addition, there is a risk of oversimplifying the analysis by integrating all of its aspects into a monetary unit (simply because there are some impacts that cannot be monetized). The difficulties for decision-makers when handling a large number of indicators can be reduced with simpler and more transparent methods, such as MCDM tools, which permit the classification of indicators according to impact categories or criteria groups and the integration of stakeholders' interests, which offer a solution in terms of scores, rankings and relative weighting (Beria et al., 2012). MCDM may be useful to address the complexity of integrating the results of economic, environmental and social criteria using standard numerical scales to compare both quantitative and qualitative variables. In addition, the MCDM serves to weigh certain criteria because, depending on the region, some of them may be more important than others (Ekener et al., 2016).

MCDM methods, also called multi-criteria decision analysis (MCDA) or multi-criteria analysis (MCA), have been popular in sustainable energy decision-making (Deveci et al., 2015; Pohekar and Ramachandran, 2004; Wang et al., 2016, 2009) due to the nature of energy projects that affect the environment and communities 
Osorio-Tejada, J., Llera-Sastresa, E., Scarpellini, S., 2017. A multi-criteria sustainability assessment for biodiesel and liquefied natural gas as alternative fuels in transport systems. Journal of Natural Gas Science and Engineering, 42, pp. 169-186. PRE-PRINT version of: $\underline{\mathrm{dx} . \text { doi.org/10.1016/j.jngse.2017.02.046 }}$

and in the same way that passenger transport systems have been analyzed by these multi-criteria techniques (Awasthi and Chauhan, 2011; Scarpellini et al., 2013; Tudela et al., 2006; Yedla and Shrestha, 2003; Zhou et al., 2007). Some authors have used MCDM to integrate social and economic indicators with environmental LCAs. Socio-economic aspects were integrated in decision-making from an LCA in the sense of involving the perceptions of people through group interviews for each environmental impact category identified in the LCA for six different processes of road maintenance (Elghali et al., 2006). Other authors have included a socioeconomic analysis in biofuels research by hybridizing the environmental LCA with different methodologies, such as multi-objective optimization (MOO), input-output analysis (IOA) or CBA (Gheewala et al., 2013; You et al., 2012). For the selection of lignocellulosic resources for the production of biofuels, an LCA and a multi-period budget (MPB) were conducted and considered the net present value and the internal rate of return as financial indicators as well as the potential for direct job creation as a social indicator (von Doderer and Kleynhans, 2014). After conducting the inventories, they used the analytic hierarchy process (AHP) to interpret the results.

Cambero and Sowlati (2014) conducted a literature review of the studies related to economic, social and environmental perspectives of biofuel production from forestry waste and found studies using MCDM (Krajnc and Domac, 2007; Päivinen et al., 2012; Werhahn-Mees et al., 2011) or MOO (Sacchelli et al., 2014; You et al., 2012) to integrate the social dimension in the sustainability assessment of these resources. Similarly, Malik et al. (2016) evaluated the sustainability of biofuels in Australia using an LCA complemented with an IOA. However, these studies do not include social indicators other than those that originated from socioeconomic analysis as the number of jobs. Employment as a social sub-criterion has been the most used by researchers in MCDM as its quantitative measurement makes the results more objective and accurate, unlike other indicators with qualitative information that are difficult to estimate.

The most popular MCDM methods that can be applied in the transport sector are (Beria et al., 2012): AHP, analytic network process (ANP), REGIME, ELECTRE family, the multi-attribute utility approach, and ADAM. MDCM method selection depends on several elements, such as the objectives, scope, expected accuracy level, stakeholders involved, availability of information, and number of indicators, among others. A MCDM method that significantly incorporates the views of the stakeholders as part of the decision-making process is the AHP developed by Saaty (1980). This method permits the building of a hierarchical tree and weighting of each indicator by pairwise comparison between criteria and indicators through a matrix to achieve a consistent and coherent management of both quantitative and qualitative data. The AHP method has been applied in transport projects to select alternatives considering mostly technical, financial/economic, and environmental criteria, and to a lesser extent social, safety, and policy criteria, Table 1. AHP-based studies have not considered market related issues because they have focused on technology and fuel alternatives for passenger transportation and their operation phase, whereas for freight transport only the location of terminals and selection of routes have been studied. Additionally, all of these studies partially analyze the factors of the transport system; some of them consider the initial and maintenance costs of vehicles or the availability of infrastructure, but not the environmental or social impacts of these factors. Likewise, some studies only consider the environmental impacts of fuel combustion, ignoring the impacts of fuel production (see Table A. 1). For these reasons, there is a gap in the studies for the assessment of alternative fuels for freight transport and studies that consider the three factors of the transport system comprehensively from a life cycle perspective. 
Osorio-Tejada, J., Llera-Sastresa, E., Scarpellini, S., 2017. A multi-criteria sustainability assessment for biodiesel and liquefied natural gas as alternative fuels in transport systems. Journal of Natural Gas Science and Engineering, 42, pp. 169-186. PRE-PRINT version of: $\mathrm{dx}$.doi.org/10.1016/j.jngse.2017.02.046

Table 1. Criteria used in AHP-based studies for sustainable alternatives in transport projects

\begin{tabular}{|c|c|c|c|c|c|c|c|}
\hline \multirow[b]{2}{*}{ Reference } & \multirow[b]{2}{*}{ Scope of study } & \multicolumn{6}{|c|}{ Criteria } \\
\hline & & 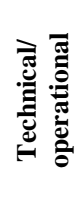 & 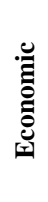 & 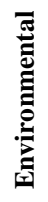 & 胥 & 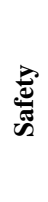 & : \\
\hline (Levine and Underwood, 1996) & Analysis of an intelligent traffic routing system & $\mathrm{x}$ & $\mathrm{x}$ & $\mathrm{x}$ & & $\mathrm{x}$ & \\
\hline (Klungboonkrong and Taylor, 1998) & Identifying priorities for urban traffic system & $\mathrm{x}$ & & $\mathrm{x}$ & & $\mathrm{x}$ & \\
\hline (Poh and Ang, 1999) & Alternative fuels for road passenger transport & $\mathrm{x}$ & $\mathrm{x}$ & $\mathrm{x}$ & $\mathrm{x}$ & $\mathrm{x}$ & \\
\hline (Tsamboulas et al., 1999) & Infrastructure investments & & $\mathrm{x}$ & $\mathrm{x}$ & & $\mathrm{x}$ & \\
\hline (Yedla and Shrestha, 2003) & Alternative fuels for road passenger transport & $\mathrm{x}$ & $\mathrm{x}$ & $\mathrm{x}$ & & & \\
\hline (Ferrari, 2003) & Road alignment variants & $\mathrm{x}$ & $\mathrm{x}$ & $\mathrm{x}$ & & & \\
\hline (Macharis et al., 2004) & Advanced driver assistance technologies & $\mathrm{x}$ & $\mathrm{x}$ & $\mathrm{x}$ & $\mathrm{x}$ & $\mathrm{x}$ & \\
\hline (Tzeng et al., 2005) & Alternative fuels for public passenger transport & $\mathrm{x}$ & $\mathrm{x}$ & $\mathrm{x}$ & & & \\
\hline (Caliskan, 2006) & Road infrastructure investments & $\mathrm{x}$ & $\mathrm{x}$ & $\mathrm{x}$ & $\mathrm{x}$ & & \\
\hline (Tudela et al., 2006) & Urban road investment & $\mathrm{x}$ & $\mathrm{x}$ & $\mathrm{x}$ & & $\mathrm{x}$ & \\
\hline (Quintero et al., 2008) & Alternative fuels production & & $\mathrm{x}$ & $\mathrm{x}$ & & & \\
\hline (Liu and Lai, 2009) & Rail infrastructure investment & $\mathrm{x}$ & & $\mathrm{x}$ & $\mathrm{x}$ & & \\
\hline (Tuzkaya, 2009) & Evaluating impacts of transportation modes & $\mathrm{x}$ & & $\mathrm{x}$ & & $\mathrm{x}$ & \\
\hline (Kayikci, 2010) & Location of intermodal freight terminals & $\mathrm{x}$ & $\mathrm{x}$ & $\mathrm{x}$ & $\mathrm{x}$ & $\mathrm{x}$ & $\mathrm{x}$ \\
\hline (Mohajeri and Amin, 2010) & Rail infrastructure investment & $\mathrm{x}$ & $\mathrm{x}$ & $\mathrm{x}$ & $\mathrm{x}$ & & $\mathrm{x}$ \\
\hline (Awasthi and Chauhan, 2011) & Passenger transport solutions & $\mathrm{x}$ & $\mathrm{x}$ & $\mathrm{x}$ & & $\mathrm{x}$ & \\
\hline (Barfod et al., 2011) & Road infrastructure investment & $\mathrm{x}$ & $\mathrm{x}$ & $\mathrm{x}$ & $\mathrm{x}$ & & \\
\hline (Portugal et al., 2011) & Location of intermodal freight terminals & $\mathrm{x}$ & $\mathrm{x}$ & $\mathrm{x}$ & & $\mathrm{x}$ & \\
\hline (Turcksin et al., 2011) & Policy to promote clean road passenger transport & $\mathrm{x}$ & $\mathrm{x}$ & $\mathrm{x}$ & $\mathrm{x}$ & & \\
\hline (Duleba et al., 2012) & Analysis of users preferences in urban bus transport & $\mathrm{x}$ & & & & $\mathrm{x}$ & \\
\hline (Haddad and Fawaz, 2012) & Alternative fuels for air transport & $\mathrm{x}$ & $\mathrm{x}$ & $\mathrm{x}$ & & & \\
\hline (Tsita and Pilavachi, 2012) & Alternative fuels for road passenger transport & $\mathrm{x}$ & $\mathrm{x}$ & $\mathrm{x}$ & $\mathrm{x}$ & & \\
\hline (Zubaryeva et al., 2012) & Identifying potential markets for electric vehicles & $\mathrm{x}$ & $\mathrm{x}$ & $\mathrm{x}$ & & & $\mathrm{x}$ \\
\hline (Jones et al., 2013) & Road infrastructure investment & $\mathrm{x}$ & & $\mathrm{x}$ & $\mathrm{x}$ & $\mathrm{x}$ & \\
\hline (Rossi et al., 2013) & Pollution-reducing policies for passenger transport & & $\mathrm{x}$ & $\mathrm{x}$ & $\mathrm{x}$ & & \\
\hline (Shiau and Liu, 2013) & Urban passenger transport solutions & $\mathrm{x}$ & & $\mathrm{x}$ & $\mathrm{x}$ & $\mathrm{x}$ & \\
\hline (Tsita and Pilavachi, 2013) & Alternative fuels for road passenger transport & $\mathrm{x}$ & $\mathrm{x}$ & $\mathrm{x}$ & $\mathrm{x}$ & & \\
\hline (Vermote et al., 2013) & Road networks for freight transport & $\mathrm{x}$ & $\mathrm{x}$ & $\mathrm{x}$ & $\mathrm{x}$ & $\mathrm{x}$ & \\
\hline (De Luca, 2014) & Public passenger transport solutions & $\mathrm{x}$ & $\mathrm{x}$ & $\mathrm{x}$ & & $\mathrm{x}$ & \\
\hline (Gardziejczyk and Zabicki, 2014) & Road alignment variants & $\mathrm{x}$ & $\mathrm{x}$ & $\mathrm{x}$ & $\mathrm{x}$ & & \\
\hline (Gogas et al., 2014) & Location of freight port terminals & $\mathrm{x}$ & & & $\mathrm{x}$ & $\mathrm{x}$ & \\
\hline (J. Javid et al., 2014) & Pollution-reducing policies for passenger transport & $\mathrm{x}$ & $\mathrm{x}$ & $\mathrm{x}$ & & & \\
\hline (Kengpol et al., 2014) & Multimodal routes for freight transport & $\mathrm{x}$ & $\mathrm{x}$ & $\mathrm{x}$ & & & $\mathrm{x}$ \\
\hline (Nosal and Solecka, 2014) & Public passenger transport solutions & $\mathrm{x}$ & $\mathrm{x}$ & $\mathrm{x}$ & & $\mathrm{x}$ & \\
\hline (Verma et al., 2014) & Policy to improve passenger mobility & $\mathrm{x}$ & $\mathrm{x}$ & $\mathrm{x}$ & & & \\
\hline (von Doderer and Kleynhans, 2014) & Resources for biofuel production & & $\mathrm{x}$ & $\mathrm{x}$ & $\mathrm{x}$ & & \\
\hline (Lanjewar et al., 2015) & Alternative fuels for road passenger transport & $\mathrm{x}$ & $\mathrm{x}$ & $\mathrm{x}$ & & & \\
\hline (Macharis et al., 2015) & Modal choice in freight transport & $\mathrm{x}$ & $\mathrm{x}$ & $\mathrm{x}$ & & $\mathrm{x}$ & \\
\hline (Ren and Lützen, 2015) & Alternative fuels for sea transport & $\mathrm{x}$ & $\mathrm{x}$ & $\mathrm{x}$ & $\mathrm{x}$ & & $\mathrm{x}$ \\
\hline (Buwana et al., 2016) & Passenger transport solutions & $\mathrm{x}$ & $\mathrm{x}$ & $\mathrm{x}$ & & $\mathrm{x}$ & \\
\hline (Curiel-Esparza et al., 2016) & Policy to improve passenger mobility & $\mathrm{x}$ & $\mathrm{x}$ & $\mathrm{x}$ & $\mathrm{x}$ & & \\
\hline
\end{tabular}

\section{Sustainability assessment methodology}

The proposed methodological approach aims to guide decision-makers to assess the sustainability of technologies for the use of alternative fuels in truck fleets. The methodology permits decision-makers to consider a comprehensive view of the community, public administration, customers, employees and owners in an analytic hierarchy evaluation process.

A detailed guide was developed that includes the steps for qualitative and quantitative assessment of the selected sub-criteria for environmental, social and economic criteria. The methodology requires sub-criteria related to market aspects in the economic criterion to assess indicators, such as the reliability of the technology, supply security and legal issues. The guide consists of the following five steps, as seen in Fig. 1: 
1) Selection of alternatives and items by factor

2) Establishment of sub-criteria and indicators

3) Pairwise comparison of alternatives

4) Weighting of criteria for evaluating scenarios

5) Sustainability indices calculation
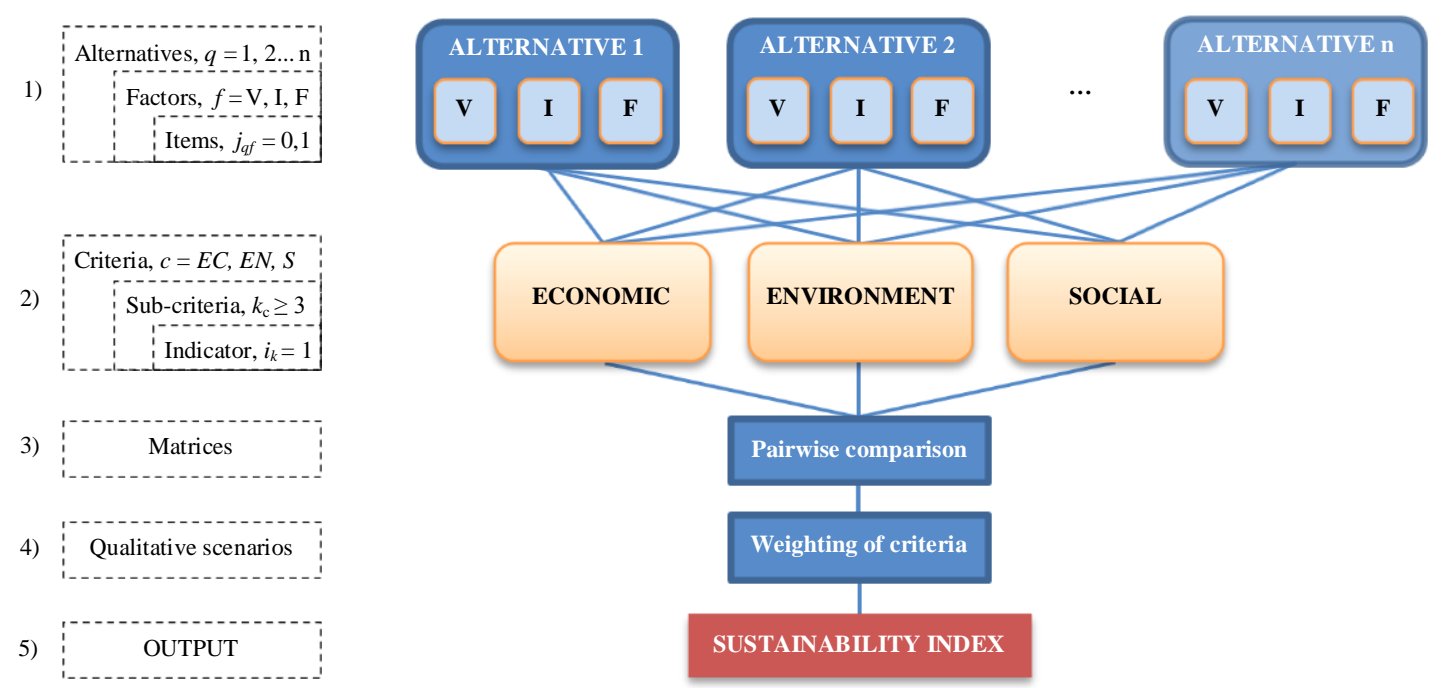

Fig. 1. Sustainable transport assessment guide

\subsection{Selection of alternatives and items by factor}

After establishing the scope and objectives of the evaluation process, alternatives $(q=1,2 \ldots n)$ and items $\left(j_{q f}\right)$ for each factor $(f)$ of the transport system, i.e., vehicles $(V)$, infrastructure $(I)$ and fuels $(F)$, which have an impact on economic $(E C)$, environmental $(E N)$ and social $(S)$ aspects, are identified through an initial market analysis.

The items must be identified based on the preliminary selection of alternatives, i.e., the traditional $(q=1)$ and new alternative $(q=2)$. All of the items that are needed to operate with an alternative fuel need to be classified according to the respective factor. For example, if operation with electricity $(q=2)$ is available only for an electric truck with lead batteries, this would require an item of the vehicles factor (i.e., $j_{2 V}=1$ ). Furthermore, if recharging the trucks is possible at a particular station that is built inside the company facilities or at a third parties' charging station located at different points in the city, both options would be items of the infrastructure factor (i.e., $j_{2 I}=2$ ). Subsequently, the type of fuel identified for both options would be the same electricity from the city's energy mix (i.e., $j_{2 F}=1$ ).

To begin the analysis, it is important to ensure that for each alternative, at least one item in one of the three factors of the transport system is identified $\left(\forall f \in q, j_{q V}+j_{q I}+j_{q F}>0\right)$. In addition, each factor cannot have more than one item $\left(\forall f \in q, j_{q f}=0,1\right)$. Therefore, if there are two or more items in one of the factors, the additional item must be converted to a new alternative $\left(j_{q f}>1 \rightarrow q=n+j_{q f}-1 \rightarrow j_{q f}=1\right)$. Hence, each new alternative will have only one item in the respective factor. In this regard, for the previous example, there would now be three alternatives: the traditional diesel truck $(q=1)$, the electric truck charged at its own station $(q=2)$ and the electric truck charged at a third parties' station $(q=3)$. 


\subsection{Establishment of sub-criteria and indicators}

For the establishment of sub-criteria $\left(\mathrm{k}_{\mathrm{c}}\right)$ and the corresponding indicators $\left(i_{k}\right)$ for the social, economic and environmental criteria, at least three sub-criteria based on the different interests of the stakeholders for each criterion should be selected. This is to assure inclusion in the economic criterion, besides financial/costs subcriteria, of other sub-criteria related to the reliability/safety of the technology and legal aspects involved in the expected performance of the investment over its lifetime.

In this regard, the three recommended sub-criteria for the economic criterion are reliability, investment and operational costs and legislation. For environmental and social criteria, the sub-criteria may vary depending on the interests of the company and the stakeholders. Among the most common environmental sub-criteria are GHG and air pollutant emissions, land use and noise, whereas for the social criterion, they are job creation, social benefits or social acceptability (Wang et al., 2009). In addition, for each sub-criterion, a valid indicator must be chosen to compare the results between the selected alternatives, e.g., square meters would be an indicator of the land used for the refueling stations and decibels would be an indicator of the noise from engines.

For the selection of sub-criteria and indicators, appropriate and available information on the market is needed as far it interacts with aspects related to technological development and legislation. This information has been defined in some studies as the technological criterion, where the main indicator is the efficiency, followed by the reliability and then the maturity of the technology (Wang et al., 2009). However, technological aspects must be evaluated in parallel with legal aspects and market trends. Those aspects should be not only be analyzed from information from suppliers but also successful cases in the same sector and studies with sufficient scientific rigor to provide accurate and consistent results. The aspects related to the reliability of the technology are: safety and performance; warranty and after-sales service; guaranteed supply and price stability of spare parts, supplies and fuel; staff training requirements; and availability of refueling stations. Some legislative aspects are: incentives for investment in technology; compliance with air quality standards, noise and safety; permitting and/or special licenses for the free circulation; specific regulations in cities and areas for restricted access due to noise, fuel type, weight or dimensions; and analysis of the expected restrictive regulation and tax benefits.

\section{3 . Pairwise comparison of alternatives}

Pairwise comparison matrices (PCM) for each sub-criterion to compare the alternatives in each factor are developed. A total of nine Global priority vectors $\left(Y_{c f}\right)$ for each criterion and factor are obtained based on the Saaty AHP guidelines (Saaty, 1980); see Appendix C.

$$
Y_{c f}=\left[y_{c f, q}\right]=\left[\begin{array}{r}
y_{c f, 1} \\
y_{c f, 2} \\
\vdots \\
y_{c f, n}
\end{array}\right],
$$

where:

$$
\begin{aligned}
& c=E C, E N, S \\
& f=V, I, F \\
& q=1,2 \ldots n
\end{aligned}
$$




\subsection{Weighting of criteria for evaluating scenarios}

Weights for each criterion $\left(W_{\mathrm{c}}\right)$ to establish different scenarios based on the interests of the stakeholders are made. The baseline scenario is constructed considering the equal importance of each of the three criteria $\left(\mathrm{W}_{\mathrm{EC}}, \mathrm{W}_{\mathrm{EN}}\right.$, and $\left.\mathrm{W}_{\mathrm{S}}\right)$, whereas scenario 1 would be established based on the interests of the decision-maker team. This team is commonly composed of strategy planners, the head of maintenance department, a member of the board of directors, the general manager and an employee representative of the company but could also involve a representative of the community or a local government.

Additional scenarios, in which weighting depends on the opinion of a certain stakeholder or the same decision-maker team based on different market expectations or potential changes in legislation, are established to understand the best alternatives in a given scenario.

\subsection{Sustainability indices calculation}

From the Global Priority Vectors of alternatives $\left(Y_{c f}\right)$ for each criterion obtained at the end of section 3.3 and weightings from section 3.4, the sustainability vector $(S V)$ in a certain scenario is obtained, in which each value in the vector is the sustainability index for each alternative $\left(s i_{q}\right)$. The highest $s i_{q}$ would be the most sustainable alternative in the assessed scenario:

$$
S V=\left[W_{E C}\left(Y_{E C V}+Y_{E C I}+Y_{E C F}\right)+W_{E N}\left(Y_{E N V}+Y_{E N I}+Y_{E N F}\right)+W_{S}\left(Y_{S V}+Y_{S I}+Y_{S F}\right)\right] \div 3,
$$

Then,

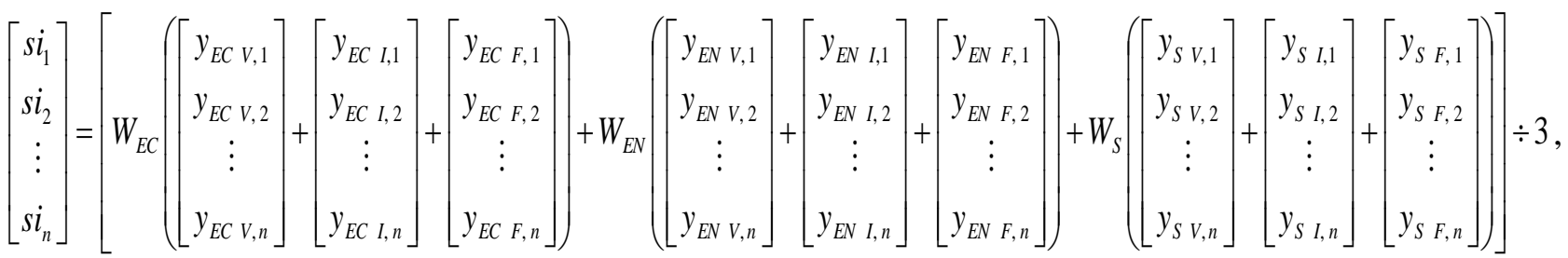

$\sum_{q=1}^{n} s i_{q}=1$

\section{Case Study: LNG and biodiesel for a Spanish road freight company}

In this case study, the objective of the company is to purchase new trucks (tractor units) for medium and long distances. It is expected that the vehicle can travel, on average, $1000 \mathrm{~km}$ (round-trip) from to the base plant in Zaragoza with or without refueling at the available stations along the routes. The methodology seeks to evaluate sustainable and clean alternative technologies, primarily to reduce the carbon footprint contribution to the transported products.

For the selection of suitable fuels for long haul transport, the European Commission recommended, through the Clean Power for Transport: A European alternative fuels strategy (European Commission, 2013), the use of liquefied petroleum gas (LPG), LNG and liquid biofuels. Although the promotion of biofuels was recommended only when advanced biofuels become commercially available on a large scale, biodiesel from traditional feedstocks, such as canola, rapeseed, sunflower, olive, palm, soybean, animal fats or waste cooking oil, are available in many refueling stations throughout Europe. Fatty acid methyl ester (FAME) is the most common biodiesel but can only be used by diesel oil mixtures in low concentrations of up to $7 \%$ for any diesel engine, which is in the diesel oil sold at refueling stations in Spain, or in mixtures of up to 30 
Osorio-Tejada, J., Llera-Sastresa, E., Scarpellini, S., 2017. A multi-criteria sustainability assessment for biodiesel and liquefied natural gas as alternative fuels in transport systems. Journal of Natural Gas Science and Engineering, 42, pp. 169-186. PRE-PRINT version of: dx.doi.org/10.1016/j.jngse.2017.02.046

$\%$ by taking extra precautions and making modifications to the engines. Therefore, FAME would not be a complete alternative to obtain significant results on sustainability indicators by replacing diesel oil. The other available biodiesel option is hydrotreated vegetable oil (HVO), which can be used directly in modern diesel engines without restrictions, and this fuel could be an alternative to assess.

The use of HVO, also known as renewable diesel, hydrogenation derived renewable diesel (HDRD) or hydrogenated biodiesel (HBD) (Neste, 2016), is approved by truck manufacturers, such as IVECO, Mercedes-Benz, Renault, Scania and Volvo (APPA, 2015). It is important to note that the market offering for LPG trucks was not found and therefore not considered in this assessment. A study in Spain stated that no European manufacturer offers medium or heavy vehicles to run LPG because it does not offer advantages in performance, emissions or prices versus natural gas (NG) (GASNAM, 2015). There are companies that offer kits to convert conventional diesel to dual fuel engines to operate with $95 \%$ LNG and $5 \%$ diesel or manufacturers that offer new trucks with $100 \%$ dedicated LNG spark ignition engines directly from the factory. For this case study, three fuel alternatives were selected: LNG, diesel oil and HVO. The main investment is the purchase of dedicated LNG 330-horsepower tractor units or diesel equivalent units to be used with diesel oil or neat HVO. Both types of trucks are domestically manufactured by the same company with Euro VI certification, which meets the technical and legal requirements of driving on European roads.

Therefore, items involved in the transport system are new tractor units, refueling stations and fuels. Although refueling stations would be built and managed by third parties, they must be considered due to their indispensability for the operation of the vehicles. Roads and other infrastructure, such as parking slots, would be the same for both types of trucks, and therefore, they were not considered in the infrastructure factor.

According to the established above in section 3.2 and the literature review, for the environmental, economic and social criteria, the most common sub-criteria in energy sustainability assessments have been $\mathrm{CO}_{2}$ or GHG emissions, initial investment and employment (Wang et al., 2009). However, in the specific case of the analysis of transport alternatives, which include mobile units, and because of the importance of the use phase, NOx and PM emissions, to assess their local impact on the air quality of urban areas, as well as their operational and maintenance costs (Awasthi and Chauhan, 2011; Tudela et al., 2006; Yedla and Shrestha, 2003; Zhou et al., 2007) and noise (Janic, 2007; Janic and Vleugel, 2012), must be considered. In the case of the social criterion, other sub-criteria have been considered in transportation projects, such as traffic accidents and congestion (Janic, 2007; Janic and Vleugel, 2012; Macharis, 2005), but because the tractor units for the alternatives are the same dimensions and mass and are driven similarly, these indicators are not affected. Other aspect that have been taken into account in the subsector of fuels production is the social benefits to the region (Blom and Solmar, 2009; Ekener et al., 2016; Gheewala et al., 2013; Krajnc and Domac, 2007; Pereira and Seabra, 2013), which must be considered to assess the social performance of the alternatives. For the sub-criteria selection and their respective indicators, as shown in Table 2, aspects such as the interests of the company, the society and the literature were considered.

In addition to the aspects that mainly concern the company related to the reliability of technology and financial indicators, legislative aspects also play an important role in decision-making in the economic criterion. The company wants to take advantage of the benefits that it could receive for improving environmental performance, such as those related to climate change mitigation and free circulation in restricted areas. In addition to a lower carbon footprint reported for the customer's products, social acceptability would be another benefit from the new fleet for the whole company and as a marketing strategy that can improve the sustainability of the business in the future. 
Osorio-Tejada, J., Llera-Sastresa, E., Scarpellini, S., 2017. A multi-criteria sustainability assessment for biodiesel and liquefied natural gas as alternative fuels in transport systems. Journal of Natural Gas Science and Engineering, 42, pp. 169-186. PRE-PRINT version of: $\underline{\mathrm{dx} . \text { doi.org/10.1016/j.jngse.2017.02.046 }}$

Table 2. Sub-criteria and indicators by criteria for each factor

\begin{tabular}{|c|c|c|c|c|}
\hline \multirow{2}{*}{ Criteria } & \multirow{2}{*}{ Sub-criteria } & \multicolumn{3}{|c|}{ Indicators by factor } \\
\hline & & Vehicle & Infrastructure & Fuels \\
\hline \multirow[t]{3}{*}{ Economic } & Initial and maintenance costs & $€, \Delta$ (maint.) & - & $€ / 100 \mathrm{~km}$ \\
\hline & Reliability & $\Delta$ Productive time & Stations quantity & Availability $^{\mathrm{b}}$ \\
\hline & Legislation & Benefits & Benefits & Benefits \\
\hline \multirow[t]{3}{*}{ Environment } & GHG emissions $^{\mathrm{a}}$ & $\mathrm{kgCO}_{2} \mathrm{eq} / \mathrm{km}$ & $\mathrm{kgCO}_{2} \mathrm{eq} / \mathrm{km}$ & $\mathrm{kgCO}_{2} \mathrm{eq} / \mathrm{km}$ \\
\hline & Air pollutants (NOx and PM emissions) & - & - & $\mathrm{g} / \mathrm{kWh}$ (each one) \\
\hline & Noise & $\Delta$ decibels & $\Delta$ decibels & - \\
\hline \multirow[t]{3}{*}{ Social } & Employment & Direct and indirect jobs & Indirect jobs & Indirect jobs \\
\hline & Social benefits ${ }^{\mathrm{c}}$ & Social benefits & Social benefits & Social benefits \\
\hline & Social acceptability & Favorability & Favorability & Favorability \\
\hline
\end{tabular}

Data for each indicator in Table 2 was obtained from secondary sources and through semi-structured indepth interviews. Quantitative values were used mainly for the economic and environmental indicators, while qualitative values were used for the social indicators because they do not depend directly on the company but on the industry and the economic activity related to each alternative fuel. A summary of the data for each indicator is presented in Table B.1. These values are converted in ratings of relative importance for the pairwise comparison between the alternatives as is described in section 3.3 to obtain global priority vectors. This process was performed according to the point (a) of Appendix $\mathrm{C}$ and is presented in Table 3. A total of twenty-seven PCM were developed by comparing the impact of the alternatives on each of the three factors according to the nine sub-criteria considered.

The LNG alternative had low ratings in the economic sub-criteria versus the diesel oil and HVO alternatives in the vehicle factor because the truck incremental cost is approximately $30 \%$ over a conventional diesel truck (DTTL, 2014). The maintenance costs of LNG trucks would be approximately $10 \%$ higher due to the extra training and potential roadside breakdowns (Chandler, 2004) combined with the mean time to repair (MTTR) and waiting time for a skilled maintenance technician with spare parts (Chandler, 2004; Jaffe et al., 2015). However, the initial cost of LNG trucks is partially compensated for by the subsidy of $20000 €$ per purchased unit by the "MOVEA" plan of the Spanish government (Spanish Government, 2015). The overruns for LNG trucks would also be compensated for by fuel cost savings of approximately $30 \%$ per $\mathrm{km}$ traveled versus the diesel oil and HVO alternatives (DLR et al., 2014; DTTL, 2014; Spanish Government, 2016a); the average LNG consumption is $25.3 \mathrm{~kg} / 100 \mathrm{~km}$ per truck, i.e., $26.21 €$, whereas the equivalent diesel truck consumes $32 \mathrm{~L} / 100 \mathrm{~km}$, i.e., $39.34 €$ (Rolande LCNG, 2015).

Legislation is also favoring the use of NG by the excise duty of $1.15 € / \mathrm{GJ}(0.056 € / \mathrm{kg})$, while for diesel oil is $0.331 € / \mathrm{L}$ (European Commission, 2016). In addition to the subsidy for the purchase of NG vehicles, the government is also subsidizing up to $100 \%$ of the registration costs and up to $50 \%$ of the cost of tolls and parking through environmental labeling (Spanish Government, 2016b). Also, due to the low noise of LNG trucks, which is about $50 \%$ lower than diesel trucks (Mercedes-Benz España, 2009; Verbeek et al., 2015), they can obtain special permits to deliver at nights in restricted urban areas (Fernandez, 2015; MercedesBenz España, 2009). The development of infrastructure have been promoted in all Member States through the Directive 2014/94/EU (European Parliament And The Council Of The European Union, 2014), which sets goals for the construction of LNG refueling stations every $400 \mathrm{~km}$.

Construction of LNG stations in Spain have grown exponentially to a total of 19 by mid-2016, whereas the number of refueling stations supplying biodiesel has declined dramatically from 470 stations in 2010 to 81 by mid-2016 (Spanish Government, 2016a), which affects the reliability of the infrastructure factor by restricting the vehicle routing problem (VRP). The decline of biodiesel refueling points was generated by terminating the tax exemption for biofuels in December 2012, which has made biodiesel unprofitable for retailers and less attractive to consumers. The Spanish Association of Biofuels Producers (APPA, 2015) is concerned about the future of the sector due to excessive requirements for local producers and the reduction 
Osorio-Tejada, J., Llera-Sastresa, E., Scarpellini, S., 2017. A multi-criteria sustainability assessment for biodiesel and liquefied natural gas as alternative fuels in transport systems. Journal of Natural Gas Science and Engineering, 42, pp. 169-186. PRE-PRINT version of: $\underline{\mathrm{dx} . \text { doi.org/10.1016/j.jngse.2017.02.046 }}$

in 2013 of the 2020 targets for the biodiesel introduction from $7 \%$ to $4.1 \%$, which forced a drop of annual biodiesel consumption from $27 \mathrm{kt}$ in 2012 to $1 \mathrm{kt}$ in 2015 and led to the closure of several refineries in Spain (CORES, 2016). This situation could affect the supply of HVO, which can be supported by imports, but does not ensure price stability. The LNG security of supply would be guaranteed due to EU measures to mitigate the disruption risks through the diversification of NG suppliers, minimum stocks and connections between the Member States and LNG terminals in ports (most of them in Spain) (GIE, 2015). Recent simulations have shown that NG disruptions would not affect the availability and price stability in Western Europe (Flouri et al., 2015; Hecking et al., 2015; Lochner, 2011; Richter and Holz, 2015).

LNG consumed in Spain is currently all imported. LNG is carried in liquid form by tanker trucks from its reception in ports to refueling stations to be used directly in vehicles. These LNG imports in 2015 came from Algeria (28.3\%), Nigeria (27.7 \%), Qatar (22.5\%), Trinidad and Tobago (7.4\%), Peru (7.1\%), Norway (5.2 $\%$ ) and Oman (0.6\%) (CORES, 2016). In the case of biodiesel, the whole feedstock to produce the HVO consumed in Spain in 2015 was imported (98.22\% palm oil and $1.78 \%$ shea butter), and $78.2 \%$ was refined domestically, mainly from Indonesian (67\%) and Malaysian $(27.6 \%)$ palm oil. The imported HVO was mainly refined in the Netherlands and Singapore and was also from palm oil (CNMC, 2016). The trade balance of diesel oil is similar to HVO. Nearly $83 \%$ of the diesel oil consumed in 2015 in Spain was refined domestically from imported crude oil from Nigeria (16.7\%), Mexico (13.7\%), Saudi Arabia (10.5\%), Angola (9.2 \%), Russia (6.2 \%), Iraq (5.4\%), Venezuela (4.9\%), Colombia (4.8\%), European countries $(11.8 \%)$ and others $(16.8 \%)$ (CORES, 2016).

Even though the refining industry leads to economic benefits and employment in relatively good conditions in Spain, the oil and gas and palm oil industries have not shown good sustainability indicators in developing countries. Many companies have been responsible for environmental impacts, such as deforestation, biodiversity damage and high GHG emissions (Vijay et al., 2016), as well as social impacts, such as negative labor conditions and disrespect for human rights, cultural heritage, indigenous communities and governance.

A case study in Jambi Province of Indonesia found that palm oil expansion seriously affected cultural heritage due to deforestation of areas inhabited by indigenous groups, who are being marginalized by destroying and polluting their environment (Manik et al., 2013). Additionally, this study stated that many of the jobs generated are for casual day laborers without fair salaries; occupational and health safety; social benefits; such as an insurance plan or pension; and the impossibility of freedom of association and collective bargaining.

The fossil oil industry has also presented potential social risks. In recent years, a negative reality regarding the production of biofuels has been slightly unfair in the media because in the case of traditional fuels, no similar social impact studies have been conducted (Ekener-Petersen et al., 2014). These authors found that the oil operations in Nigeria and Russia show very high risks of negative social impacts related to labor conditions, freedom of association, right to strike and minimum wages, as well as social conflicts, disrespect for indigenous rights and governance issues such as corruption.

Oil and gas operations are also controversial because in some exporting countries, the extraction methods, such as fracking, could affect the availability and quality of water and soil (Bilgen and Sarkaya, 2016; Stickley, 2012). However, the main LNG and crude oil suppliers of Spain are still extracting these resources by conventional methods. Analyses of the social and environmental impacts of the oil and gas industry in Nigeria claimed that the most serious impacts occurred specifically due to oil operations in the Niger Delta region, where millions of barrels of crude oil have been spilled into the environment and have degraded the drinking water and sources of livelihoods and consequently led to poverty and violence (Ebegbulem et al., 2013; Nwankwo, 2015; Omokaro, 2009). Specifically for NG, this industry has better records for sustainability in comparison with other fossil fuels (Marcogaz, 2008). All of these arguments were considered to set the qualitative values for the social benefits sub-criterion. Because of the damage to the livelihoods of communities where crude oil and palm oil are extracted, poor values for diesel and HVO were set compared to the LNG alternative. 
Osorio-Tejada, J., Llera-Sastresa, E., Scarpellini, S., 2017. A multi-criteria sustainability assessment for biodiesel and liquefied natural gas as alternative fuels in transport systems. Journal of Natural Gas Science and Engineering, 42, pp. 169-186. PRE-PRINT version of: $\underline{\mathrm{dx} . \text { doi.org/10.1016/j.jngse.2017.02.046 }}$

Regarding environmental issues, palm oil expansion in Malaysia and Indonesia has destroyed carbon-rich tropical forests (45\% of palm oil crops were planted in forested areas (Vijay et al., 2016)). HVO produced from palm oil could generate approximately $16 \%$ more GHG emissions than diesel oil if the indirect land use change (ILUC) is considered (Verbeek et al., 2015). In general, several studies have shown that during the land clearing of tropical forests and peatlands, high GHG stocks are released, which take decades or centuries to be compensated (Fargione et al., 2008; Gibbs et al., 2008; Wicke et al., 2008).

The use of LNG has not shown significant GHG emissions reduction if the lower energy efficiency of this fuel than diesel oil, and HVO is considered. That is, per km traveled, LNG combustion in heavy engines could reduce GHG emissions by up to $20 \%$, whereas considering the extra-energy needed for liquefaction, transportation and distribution, the life-cycle reduction rate would be between $-10 \%$ to $10 \%$ compared with diesel emissions (Osorio-Tejada et al., 2017). Regarding the air pollutants released during fuel combustion in Euro VI trucks, in comparison to diesel oil, LNG could reduce more than $50 \%$ NOx and $90 \%$ PM (Rolande LCNG, 2015; Verbeek et al., 2015), whereas HVO reduces approximately $10 \%$ NOx and $27 \%$ PM (Neste, 2016). The results from the comparison between HVO and diesel are the average of experiments in HDVs with different Euro standards, hence for Euro VI vehicles the NOx and PM emissions would be practically the same. The construction of vehicles and infrastructure do not represent large differences in terms of GHG and air pollutants. The operation of LNG refueling produces equal noise and consumes more electricity than diesel and biofuel stations, but this environmental impact is already included in the LCA of the fuels.

For the social sub-criteria, social acceptability had the greatest rating for LNG due to the negative perceptions of diesel combustion and the land and food issues related to biofuels. The favorability index was calculated through semi-structured in-depth interviews to the stakeholders with questions about the relevance in the environmental and socioeconomic impact of alternative fuels in each factor. NG vehicles are considered to be cleaner than diesel vehicles, although some people think NG vehicles and refueling stations involve risks, such as explosions or poisoning by leaks (DTTL, 2014). People rarely know the differences between the LNG, diesel and HVO stations; hence the favorability index is fair for the three alternatives. For the employment sub-criterion, the company would not hire new workers regardless of the selected alternative. However, the selection would generate indirect employment. Based on an IOA economic model developed by Deloitte, the market of NG in road transport would employ the $1.4 \%$ of total workforce in Spain by 2045 (DTTL, 2014). To evaluate the company's specific contribution to these indirect jobs, qualitative values were considered to be converted into the respective ratings for the pair-wise comparison matrix. New jobs in the construction of refueling stations and LNG distribution market would be generated (DTTL, 2014). For the vehicle factor, LNG trucks require a slightly higher employment rate per manufactured unit, but this rate is not enough to be significant. The maintenance and repair activities are performed by specialized external technicians for both diesel and LNG trucks, and therefore, an equally preferred rating was considered. For the fuels factor, the refining industry in Spain awarded advantages to HVO and diesel oil over the LNG alternative, and considering the low quality of employment in palm oil plantations, HVO rated lower than the diesel oil alternative. 
Osorio-Tejada, J., Llera-Sastresa, E., Scarpellini, S., 2017. A multi-criteria sustainability assessment for biodiesel and liquefied natural gas as alternative fuels in transport systems. Journal of Natural Gas Science and Engineering, 42, pp. 169-186. PRE-PRINT version of: $\underline{\mathrm{dx} . \mathrm{doi} . \mathrm{org} / 10.1016 / \mathrm{j} . j n g s e .2017 .02 .046}$

Table 3. Ratings of the PCM by sub-criteria

\begin{tabular}{|c|c|c|c|c|c|c|c|c|c|c|}
\hline Factors & Alternatives & $\begin{array}{l}\text { Initial and } \\
\text { maint. costs }\end{array}$ & Reliability & Legislation & GHG & $\begin{array}{l}\text { Air } \\
\text { pollutants }\end{array}$ & Noise & Employment & $\begin{array}{l}\text { Social } \\
\text { benefits }\end{array}$ & $\begin{array}{l}\text { Social } \\
\text { acceptability }\end{array}$ \\
\hline \multirow[t]{3}{*}{ Vehicles } & $\begin{array}{l}\text { LNG vs. } \\
\text { Diesel }\end{array}$ & $1 / 3$ & $1 / 3$ & 5 & 1 & 1 & 7 & 1 & 1 & 3 \\
\hline & $\begin{array}{l}\text { LNG vs. } \\
\text { HVO }\end{array}$ & $1 / 3$ & $1 / 3$ & 5 & 1 & 1 & 7 & 1 & 1 & 3 \\
\hline & $\begin{array}{l}\text { Diesel vs. } \\
\text { HVO }\end{array}$ & 1 & 1 & 1 & 1 & 1 & 1 & 1 & 1 & 1 \\
\hline \multirow[t]{3}{*}{ Infrastructure } & $\begin{array}{l}\text { LNG vs. } \\
\text { Diesel }\end{array}$ & 1 & $1 / 9$ & 3 & 1 & 1 & 1 & 3 & 3 & 1 \\
\hline & $\begin{array}{l}\text { LNG vs. } \\
\text { HVO }\end{array}$ & 1 & $1 / 3$ & 3 & 1 & 1 & 1 & 3 & 3 & 1 \\
\hline & $\begin{array}{l}\text { Diesel vs. } \\
\text { HVO }\end{array}$ & 1 & 7 & 1 & 1 & 1 & 1 & 1 & 1 & 1 \\
\hline \multirow[t]{3}{*}{ Fuels } & $\begin{array}{l}\text { LNG vs. } \\
\text { Diesel }\end{array}$ & 7 & 1 & 5 & 1 & 5 & 1 & $1 / 5$ & 5 & 5 \\
\hline & $\begin{array}{l}\text { LNG vs. } \\
\text { HVO }\end{array}$ & 7 & 3 & 5 & 3 & 5 & 1 & $1 / 3$ & 3 & 3 \\
\hline & $\begin{array}{l}\text { Diesel vs. } \\
\text { HVO }\end{array}$ & 1 & 3 & 1 & 3 & 1 & 1 & 3 & $1 / 3$ & $1 / 3$ \\
\hline
\end{tabular}

For some of the chosen sub-criteria, the indicators contain qualitative data that might not be very accurate given the lack of information for a particular factor. In addition, because of the inexperienced market for LNG technology, most of the information was obtained from demonstration studies and experimentation performed by different manufactures in other countries. These considerations were taken into account along with the interests of the company to rate the importance of specific sub-criterion against one another and to reduce its weight in the final assessment (Table 4).

Table 4. Sub-criteria pairwise comparison and priority vectors

\begin{tabular}{lllll}
\hline Sub-criteria pairwise comparison matrices & $\begin{array}{c}\text { S. Priority } \\
\text { vectors (SPV) }\end{array}$ \\
\hline $\begin{array}{l}\text { Economic } \\
\text { Initial and } \\
\text { maint. costs }\end{array}$ & 1 & 1 & 3 & \\
Reliability & 1 & 1 & 3 & 0.43 \\
Legislation & $1 / 3$ & $1 / 3$ & 1 & 0.43 \\
\hline & & & & 0.14 \\
Environment & GHG & Air & Noise & \\
\hline GHG & 1 & pollutants & & \\
Air pollutants & $1 / 5$ & 5 & 3 & 0.63 \\
Noise & $1 / 3$ & 1 & $1 / 3$ & 0.11 \\
\hline & & 3 & 1 & 0.26 \\
Social & Employment & Social & Social & \\
\hline Employment & 1 & benefits & acceptability & \\
Social benefits & $1 / 5$ & 5 & 3 & 0.63 \\
Social & $1 / 3$ & 1 & $1 / 3$ & 0.11 \\
acceptability & & 3 & 1 & 0.26 \\
\hline
\end{tabular}

After performing the rating for the PCM in Table 3, the MP is obtained, which is multiplied by the subcriteria priority vectors (SPV) in Table 4. Consequently, global priority vectors $\left(Y_{c f}\right)$ for each criterion were obtained (Table 5). 
Osorio-Tejada, J., Llera-Sastresa, E., Scarpellini, S., 2017. A multi-criteria sustainability assessment for biodiesel and liquefied natural gas as alternative fuels in transport systems. Journal of Natural Gas Science and Engineering, 42, pp. 169-186. PRE-PRINT version of: $\underline{\mathrm{dx} . \text { doi.org/10.1016/j.jngse.2017.02.046 }}$

\section{Table 5. Global Priority Vectors}

\begin{tabular}{llcccc}
\hline \multirow{2}{*}{ Criteria } & \multirow{2}{*}{ Factors } & \multirow{2}{*}{$\boldsymbol{Y}_{\boldsymbol{c}}$} & \multicolumn{3}{c}{ Alternatives $(q)$} \\
\cline { 4 - 6 } \cline { 4 - 5 } Economic & Vehicles & $Y_{E C V}$ & 0.22 & 0.39 & 0.39 \\
& Infrastructure & $Y_{E C I}$ & 0.26 & 0.50 & 0.24 \\
& Fuels & $Y_{E C F}$ & 0.62 & 0.25 & 0.13 \\
\hline \multirow{2}{*}{ Environment } & Vehicles & $Y_{E N V}$ & 0.45 & 0.28 & 0.28 \\
& Infrastructure & $Y_{E N I}$ & 0.33 & 0.33 & 0.33 \\
& Fuels & $Y_{E N F}$ & 0.43 & 0.37 & 0.19 \\
\hline \multirow{2}{*}{ Social } & Vehicles & $Y_{S V}$ & 0.40 & 0.30 & 0.30 \\
& Infrastructure & $Y_{S I}$ & 0.53 & 0.23 & 0.23 \\
& Fuels & $Y_{S F}$ & 0.30 & 0.44 & 0.26 \\
\hline
\end{tabular}

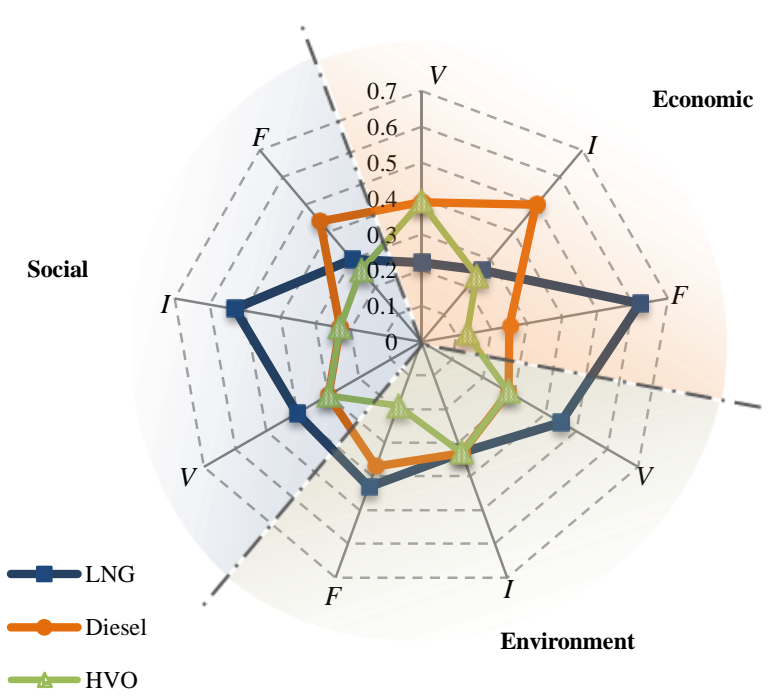

Fig. 2. Scores of the global priority vectors

Table 5 shows the scores for each alternative according to the impact on each factor of a certain criterion. A particularity of these results is that the environmental criterion did not provide higher scores for LNG despite the air pollution and noise benefits. This is because the GHG emissions were the most important environmental sub-criterion for the company objectives, whereas air pollution was considered to be minor because the trucks meet the Euro VI standard, as shown in Table 4. Moreover, because employment is the main social concern in the Spanish community (Center for Sociological Research, 2016), this sub-criterion increases the social performance of the alternatives that generate some direct or indirect jobs.

The global priority vectors are represented in a radar chart (Fig. 2), where on a scale from 0 to 1, a high score indicates a good performance of the alternative in the specific criterion and factor. The chart shows that HVO was mainly affected in the fuel factor by the current lack of government incentives and the environmental issues of the palm oil production by considering the ILUC. The greatest strengths of diesel oil over the other alternatives were due to the high availability of refueling stations, which improved the reliability of the operation, and secondly, the indirect employment in local diesel refineries. The LNG alternative had the best scores in the economic criterion for the fuel factor due to low fuel costs, security of the supply and government incentives to use this fuel in transportation. In addition, the social acceptability of NG vehicles and indirect employment for the infrastructure development for a new market favored this alternative.

At this point, LNG would be the selected alternative because of the high scores in most aspects, except for the economic criterion for vehicles and infrastructure and the social criterion for the fuel factor, for which the 
diesel oil alternative is stronger. However, the final decision depends on the weight that the decision-makers give to each criterion. The weighting according to different scenarios is presented in Table 6 . The scenarios were established through the semi-structured in-depth interviews to the different stakeholders. The scenario 1 reflects the interests of the company owners; the scenario 2 was weighted according the views of journalists, politicians and experts from environmental organizations which reflects the interests of the society; the scenario 3 represents the views of independent truck owners and other road freight companies, specially SMEs, who mostly base the decision making only on the economic criterion, while the scenario 4 was established as a hypothetical case in which importance is given to the environmental criterion but not the social one.

\section{Table 6. Weighted scenarios by criteria}

\begin{tabular}{cccc}
\hline \multirow{2}{*}{ Scenarios } & \multicolumn{3}{c}{ Criteria } \\
\cline { 2 - 4 } & $\begin{array}{c}\text { Economic } \\
\left(\mathrm{W}_{\mathrm{EC}}\right)\end{array}$ & $\begin{array}{c}\text { Environment } \\
\left(\mathrm{W}_{\mathrm{EN}}\right)\end{array}$ & $\begin{array}{c}\text { Social } \\
\left(\mathrm{W}_{\mathrm{S}}\right)\end{array}$ \\
\hline 0 & 0.33 & 0.33 & 0.33 \\
1 & 0.50 & 0.30 & 0.20 \\
2 & 0.10 & 0.40 & 0.50 \\
3 & 1.00 & 0.00 & 0.00 \\
4 & 0.50 & 0.50 & 0.00 \\
\hline
\end{tabular}

Sustainability indices $\left(s i_{q}\right)$ were obtained for each alternative in each scenario, where the highest value for scenario 1 would be the most sustainable alternative for the decision-maker team (Fig. 3).

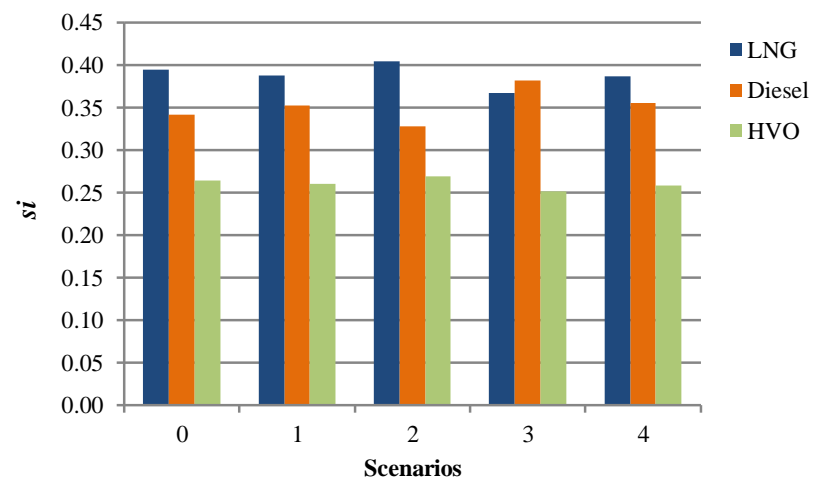

Fig. 3. Sustainability indices by scenario

Although the results in Fig. 3 mildly indicate that the best alternative for both the baseline and decisionmaker scenarios is the implementation of LNG, this alternative improves whenever the weight of the economic criterion is decreased, as in scenario 2. In the third scenario, where the whole importance is given to the economic criterion, the diesel alternative is strengthened due to the reliability sub-criterion. For this reason, if the technological reliability and availability of refueling stations were improved, LNG trucks would be a better option. 


\section{Discussion and sensitivity analysis}

The consideration of market issues, such as energy security, price stability, social acceptability, technology maturity and infrastructure development perspectives, allows the comprehensive analyzation of the performance of alternative fuels in private freight companies. Most of the multi-criteria studies as referenced in Table A. 1 basically consider the capital and operational costs into the economic criterion, while for the social and environmental criteria, only the direct impacts are considered; in other words, the impacts of fuel production, infrastructure construction and vehicle manufacturing are ignored.

The results of the case study would have been affected if market issues had not been included in the economic criterion. For example,

Fig. 4 shows the sustainability indices for three cases without considering the reliability, legislation, and social acceptability sub-criteria. In chart (a) the LNG alternative would be largely the best alternative, mainly due to low fuel costs. If in addition to this analysis, the life-cycle perspectives were not considered, LNG would continue to outperform the diesel and HVO alternatives, which are matched, as is shown in chart (b). This is mainly due to the impact of fuel combustion, since at this phase the LNG emits up to $20 \%$ less GHG than diesel and HVO, and the environmental and social impacts of fuels production are disregarded. However, since the availability of refueling stations is extremely important in freight operations, this indicator was added to the analysis in chart (c), affecting the LNG index and even causing it to fall below the original case study (Fig. 3) because this analysis does not consider the legislative outlooks for the infrastructure development and operational advantages that benefit the market of LNG technology.

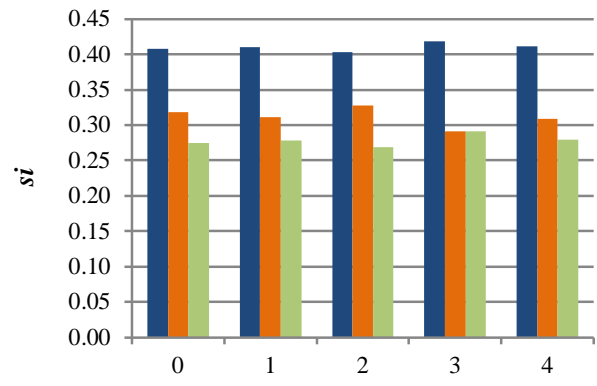

(a) No market related sub-criteria

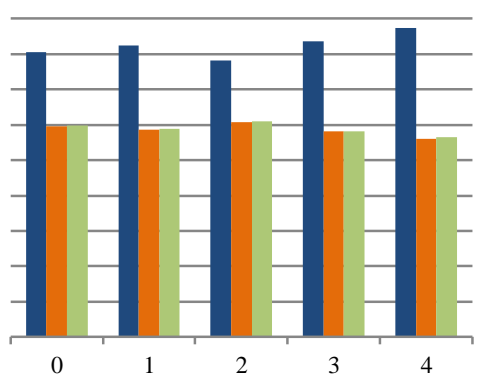

(b) No market related sub-criteria No life-cycle perspectives

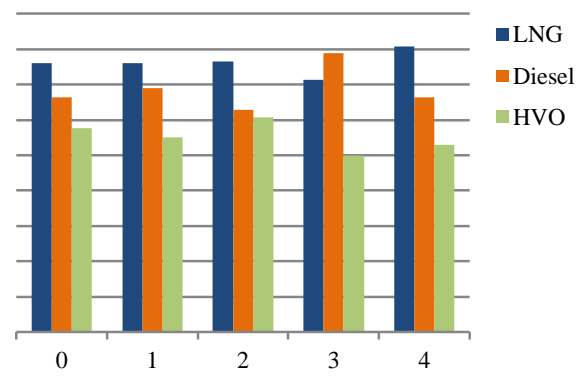

(c) No market related sub-criteria No life-cycle perspectives (considering the availability of stations)

Fig. 4. Sustainability indices by scenario using traditional sub-criteria

For all the above reasons, the results of the case study in Fig. 3 more accurately represent the performance of the alternatives in each weighted scenario. However, despite the consistency of the results in favor of LNG in most scenarios, there are some sub-criteria that present high uncertainty, requiring in some cases sensitivity analyses.

In several studies based on multi-criteria methods, sensitivity analyses have been performed primarily to assess the results by changes in weighting of criteria or sub-criteria (Awasthi and Chauhan, 2011; Deveci et al., 2015; Pohekar and Ramachandran, 2004; Streimikiene et al., 2016). However, there are indicators that may affect the results even before the weighting processes, due to the susceptible changes in their values that generate changes in the ratings established in the pairwise comparison process in Table 3. The most susceptible indicators are those that can be affected by political decisions or changes in community perceptions, such as fuel costs or the social acceptability of vehicles with new technologies, respectively.

At present, the excise duty for NG in Spain and in most European countries is very low or exempt. If the government decides to tax NG for propulsion purposes, the highest LNG score in the global priority vectors 
Osorio-Tejada, J., Llera-Sastresa, E., Scarpellini, S., 2017. A multi-criteria sustainability assessment for biodiesel and liquefied natural gas as alternative fuels in transport systems. Journal of Natural Gas Science and Engineering, 42, pp. 169-186. PRE-PRINT version of: $\underline{\mathrm{dx} . \text { doi.org/10.1016/j.jngse.2017.02.046 }}$

would be negatively affected. On the other hand, in the event of an accident related to the storage system of any NG vehicle, the social acceptability would be greatly reduced.

In the event that the government decides to tax the NG in the same rate as diesel oil, i.e. $0.453 € / \mathrm{kg}$ of LNG, the consumer price at the station would increase by $46 \%$. In this situation, the costs savings of using LNG, by $\mathrm{km}$ traveled, would be reduced from $30 \%$ to around $2.5 \%$ compared to diesel oil. The ratings in Table 3 for LNG compared to diesel and HVO in the fuels factor and the costs sub-criterion would change from 7 (very strongly preferred) to 1 (equally preferred). Likewise, this situation means a vulnerability of the legislation for the introduction of LNG, reducing the rating in the legislation sub-criterion from 5 (strongly preferred) to 1 for the fuels factor.

In the case of the social acceptability reduction as a result of a major NG vehicle accident, the ratings for LNG in the vehicles factor would change from 3 (moderately preferred) to $1 / 7$ (very strongly not preferred). Also, the ratings for the fuels and infrastructure factors could be reduced to $1 / 3$ and $1 / 5$ compared to diesel and HVO, respectively. The final results for each hypothetical case are presented in Fig. 5.

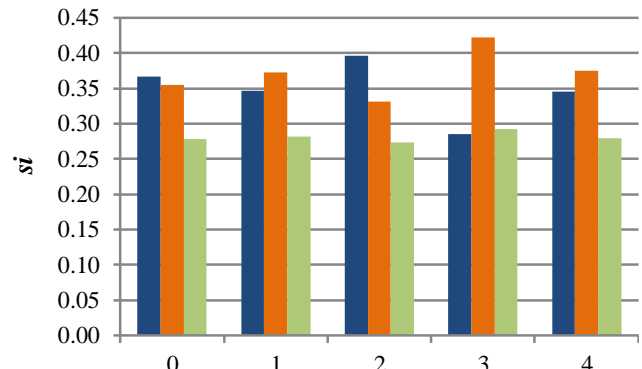

(a) NG excise duty increase

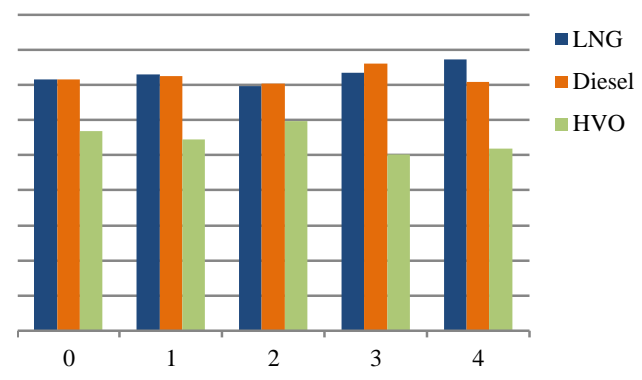

(b) NG vehicle accident

Fig. 5. Sustainability indices by scenario (Hypothetical cases)

The two main concerns for company owners would negatively affect the LNG alternative but in different proportions as seen in Fig. 5. For the company's scenario, in the case of a taxation increase to NG, LNG would not be an attractive option, while in the event of a NG vehicle accident; LNG would match with the diesel alternative.

\section{Conclusions}

Decision-making related to energy resources has been a complex process due to its significant economic, environmental and social impacts, which require the use of quantitative and qualitative indicators for the selection of alternatives that meet the expectations of different stakeholders. This is where MCDM-based models have been useful to guide and solve decision problems in the public and private sectors.

Because of the interest of private companies to use alternative fuels in their fleets for urban and inter-urban transport, a methodology for assessing the sustainability of these alternatives and taking into account the factors involved in the transport system was developed. The methodology presented in this paper ensures an assessment in the broad sense of sustainability; considering economic, environmental and social criteria. Furthermore, this methodology involves the views and interests of decision-makers and different stakeholders to prepare scenarios as a sensitivity analysis. 
From the case study and sensitivity analysis is demonstrated that omitting market aspects and life-cycle perspectives generates much more optimistic results for the LNG alternative than the original case study and at the same time do not reveal the true critical aspects to the natural gas vehicle deployment.

For the LNG introduction as fuel for freight transport, in addition to improving the reliability of the technology and the availability of stations, is also necessary to have legislative security, which guarantees the non-increase of taxes on NG for several years to ensure at least an acceptable payback for investors. Political decisions that increase the price of LNG to the diesel levels would restrain the introduction of this fuel, even more than negative community perceptions of these technologies. Nevertheless, governments, manufacturers and NG traders must perform awareness campaigns about environmental and safety issues to prevent that widespread fears in society limit the market development.

The case study revealed, by weighted scenarios, a consistency in the results, which was mainly due to the use of three sub-criteria for each evaluated criterion. Based on these results, it could be argued that this methodology can eliminate uncertainties and dilemmas generated in decision-making when the interests of a certain stakeholder incorrectly set the criteria and sub-criteria weights, which could tip the favorability toward a different alternative. This consistency could ensure the success of the alternative in the long-term dynamic environment, which is the market for alternative fuels for transport and influenced by variables related to oil trade, socio-political interests or changes in community perceptions.

\section{Nomenclature}

$i$ indicator

$j$ item

$k$ sub-criterion

si sustainability index for a specific alternative

$W$ weight for each criterion

$Y$ global priority vector of alternatives in a specific criterion and factor

$y$ value for a specific alternative in the global priority vector

\section{Subscripts and superscripts}

$c$ criterion

ECeconomics criterion

ENenvironmental criterion

$f$ factor

$F$ fuel factor

$I$ infrastructure factor

$q$ alternative

$S$ social criterion

$V$ vehicles factor

\section{Acknowledgements}

This work was co-funded by Colciencias grant 646/2014 and the Spanish Ministry of Economy and Competitiveness project ECO2013-45599-R. The authors also appreciate the useful reviewers' comments which improved the manuscript. 


\section{Appendix A}

The literature review in Table A. 1 only considers peer-reviewed studies that not only included technical and economic criteria but also environmental and social criteria. The criteria classification does not exactly represent the criteria considered in each study. Referenced authors classified the sub-criteria in different ways. For example, in some studies, the safety and congestion sub-criteria were classified into social criterion, while other studies classified them into technical or operational criterion. Similarly, the noise sub-criterion was classified into environmental criterion and sometimes into social criterion. For that reason, in addition to the economic, environmental, and social criteria, other criteria were added to the classifications.

Table A. 1. Detailed sub-criteria used in AHP-based studies for sustainable alternatives in transport projects

\begin{tabular}{|c|c|c|c|c|c|c|c|}
\hline \multirow[b]{2}{*}{ Reference } & \multirow{2}{*}{ Scope of study } & \multicolumn{6}{|c|}{ Criteria } \\
\hline & & Technical/operational & Economic & Environmental & Social & Safety & Policy \\
\hline $\begin{array}{l}\text { (Levine and Underwood, } \\
\text { 1996) }\end{array}$ & $\begin{array}{l}\text { Analysis of an intelligent } \\
\text { traffic routing system }\end{array}$ & $\begin{array}{l}\text { Individual travel time } \\
\text { Commercial travel time } \\
\text { Driving difficulty }\end{array}$ & Tax costs & $\begin{array}{l}\text { Emissions (air pollution) } \\
\text { Energy use }\end{array}$ & & Collisions & \\
\hline $\begin{array}{l}\text { (Klungboonkrong and } \\
\text { Taylor, 1998) }\end{array}$ & $\begin{array}{l}\text { Priorities for urban traffic } \\
\text { system }\end{array}$ & Difficulty to access & & $\begin{array}{l}\text { Noise } \\
\text { Land use }\end{array}$ & & $\begin{array}{l}\text { Pedestrian } \\
\text { safety }\end{array}$ & \\
\hline (Poh and Ang, 1999) & $\begin{array}{l}\text { Alternative fuels for } \\
\text { passenger transport }\end{array}$ & $\begin{array}{l}\text { Security of supply } \\
\text { Local technical support } \\
\text { New infrastructure }\end{array}$ & $\begin{array}{l}\text { All producer and } \\
\text { consumer costs }\end{array}$ & Emission of harmful gases & $\begin{array}{l}\text { Consumer } \\
\text { preferences }\end{array}$ & Safety & \\
\hline (Tsamboulas et al., 1999) & Infrastructure investments & & Cost-benefit & $\begin{array}{l}\text { Noise, air pollution } \\
\text { Landscape quality }\end{array}$ & & Safety & \\
\hline (Ferrari, 2003) & Road alignment variants & Congestion & Investment cost & $\begin{array}{l}\text { Air pollution } \\
\text { Land use }\end{array}$ & & & \\
\hline $\begin{array}{l}\text { (Yedla and Shrestha, } \\
\text { 2003) }\end{array}$ & $\begin{array}{l}\text { Alternative fuels for } \\
\text { passenger transport }\end{array}$ & $\begin{array}{l}\text { Technological preparedness/availability } \\
\text { Adaptability } \\
\text { Implementation barriers }\end{array}$ & Costs & $\begin{array}{l}\text { Emission reduction potential } \\
\text { Energy efficiency }\end{array}$ & & & \\
\hline (Macharis et al., 2004) & $\begin{array}{l}\text { Advanced driver assistance } \\
\text { technologies }\end{array}$ & $\begin{array}{l}\text { Time reduction } \\
\text { Technical feasibility } \\
\text { Driver comfort }\end{array}$ & $\begin{array}{l}\text { User cost } \\
\text { Public expenditure }\end{array}$ & Noise, emissions & $\begin{array}{l}\text { Socio/political } \\
\text { acceptability }\end{array}$ & $\begin{array}{l}\text { Driver and } \\
\text { third party } \\
\text { safety }\end{array}$ & \\
\hline (Tzeng et al., 2005) & $\begin{array}{l}\text { Alternative fuels for public } \\
\text { passenger transport }\end{array}$ & $\begin{array}{l}\text { Energy supply (reliability) } \\
\text { Vehicle capability and road facility } \\
\text { Speed of traffic flow } \\
\text { Sense of comfort }\end{array}$ & $\begin{array}{l}\text { Implementation } \\
\text { Maintenance costs } \\
\text { Industrial relationship }\end{array}$ & $\begin{array}{l}\text { Air pollution } \\
\text { Noise pollution } \\
\text { Energy efficiency }\end{array}$ & & & \\
\hline
\end{tabular}




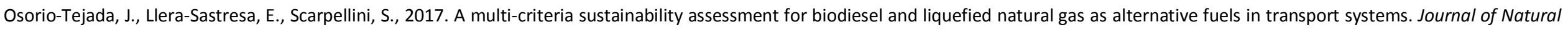
Gas Science and Engineering, 42, pp. 169-186. PRE-PRINT version of: $\underline{\mathrm{dx} . \text { doi.org/10.1016/i.jngse.2017.02.046 }}$

Table A. 1. (continued)

\begin{tabular}{|c|c|c|c|c|c|c|c|}
\hline \multirow[b]{2}{*}{ Reference } & \multirow[b]{2}{*}{ Scope of study } & \multicolumn{6}{|c|}{ Criteria } \\
\hline & & Technical/operational & Economic & Environmental & Social & Safety & Policy \\
\hline (Caliskan, 2006) & $\begin{array}{l}\text { Road infrastructure } \\
\text { investments }\end{array}$ & $\begin{array}{l}\text { Applicability of technical specification } \\
\text { Suitability to the master plan Passenger } \\
\text { traffic } \\
\text { Generated capacity }\end{array}$ & $\begin{array}{l}\text { Operation and } \\
\text { maintenance cost } \\
\text { Impact on general } \\
\text { transport system }\end{array}$ & Impact on ecosystem & $\begin{array}{l}\text { Social development } \\
\text { Impact on historical values } \\
\text { Suitability to the development } \\
\text { of the city, region and country }\end{array}$ & & \\
\hline $\begin{array}{l}\text { (Tudela et al., } \\
\text { 2006) }\end{array}$ & Urban road investment & $\begin{array}{l}\text { Travel time, operation cost reduction, delays } \\
\text { reduction, accessibility }\end{array}$ & $\begin{array}{l}\text { Investment } \\
\text { Maintenance }\end{array}$ & $\begin{array}{l}\text { Noise, air pollution, visual } \\
\text { intrusion } \\
\text { Fuel saving }\end{array}$ & & $\begin{array}{l}\text { Accident } \\
\text { reduction }\end{array}$ & \\
\hline $\begin{array}{l}\text { (Quintero et al., } \\
\text { 2008) }\end{array}$ & Alternative fuels production & & Net present value & $\begin{array}{l}\text { Potential environmental } \\
\text { impact }\end{array}$ & & & \\
\hline $\begin{array}{l}\text { (Liu and Lai, } \\
\text { 2009) }\end{array}$ & $\begin{array}{l}\text { Rail infrastructure } \\
\text { investment }\end{array}$ & $\begin{array}{l}\text { Public facility and transportation } \\
\text { inaccessibility } \\
\text { Community disconnection }\end{array}$ & & $\begin{array}{l}\text { Impact on air, water, soil. } \\
\text { and biodiversity } \\
\text { Noise, solid waste } \\
\text { Land use and landscape }\end{array}$ & $\begin{array}{l}\text { Cultural heritage destruction, } \\
\text { Life quality decline, } \\
\text { Economic activity disturbance }\end{array}$ & & \\
\hline (Tuzkaya, 2009) & $\begin{array}{l}\text { Evaluating impacts of } \\
\text { transportation modes }\end{array}$ & $\begin{array}{l}\text { Transport capacity of the vehicle } \\
\text { Infrastructure of the transportation network } \\
\text { Seasonal affects }\end{array}$ & & $\begin{array}{l}\text { Noise, } \mathrm{CO}_{2} \text { reduction } \\
\text { Effects on open land and } \\
\text { wildlife } \\
\text { Undesirable view } \\
\text { Energy use }\end{array}$ & & Safety & \\
\hline (Kayikci, 2010) & $\begin{array}{l}\text { Location of intermodal } \\
\text { freight terminals }\end{array}$ & $\begin{array}{l}\text { Intermodal operation: transport time, } \\
\text { services availability, coordination, quality, } \\
\text { connectivity, interoperability } \\
\text { Transshipment and Import/export volume, } \\
\text { mobility and congestion }\end{array}$ & $\begin{array}{l}\text { Transport cost } \\
\text { International } \\
\text { market accessibility }\end{array}$ & $\begin{array}{l}\mathrm{CO}_{2} \\
\text { Land use } \\
\text { Hazardous materials } \\
\text { Energy use }\end{array}$ & $\begin{array}{l}\text { Socioeconomic development } \\
\text { Spatial development }\end{array}$ & Accidents & $\begin{array}{l}\text { Border crossing } \\
\text { Political, } \\
\text { economic and } \\
\text { social stability }\end{array}$ \\
\hline $\begin{array}{l}\text { (Mohajeri and } \\
\text { Amin, 2010) }\end{array}$ & $\begin{array}{l}\text { Rail infrastructure } \\
\text { investment }\end{array}$ & $\begin{array}{l}\text { Rail related (adaptability, accessibility, } \\
\text { coordination) } \\
\text { Passenger related (accessibility, journey } \\
\text { time, proximity) }\end{array}$ & $\begin{array}{l}\text { Return of } \\
\text { investment cost }\end{array}$ & $\begin{array}{l}\text { Noise, air, visual pollution } \\
\text { Architecture and urbanism } \\
\text { Land uses }\end{array}$ & $\begin{array}{l}\text { Opportunity cost of existing } \\
\text { jobs } \\
\text { Creating added value for the } \\
\text { region } \\
\text { Decrease in passengers cost }\end{array}$ & & $\begin{array}{l}\text { Coordination } \\
\text { with urban } \\
\text { development } \\
\text { plans }\end{array}$ \\
\hline $\begin{array}{l}\text { (Awasthi and } \\
\text { Chauhan, 2011) }\end{array}$ & Passenger transport solutions & $\begin{array}{l}\text { User satisfaction, congestion levels, number } \\
\text { of users, Accessibility }\end{array}$ & Costs & $\begin{array}{l}\text { Air quality } \\
\text { Noise perception } \\
\text { Fuel consumption }\end{array}$ & & Security & \\
\hline $\begin{array}{l}\text { (Barfod et al., } \\
\text { 2011) }\end{array}$ & $\begin{array}{l}\text { Road infrastructure } \\
\text { investment }\end{array}$ & Accessibility & Cost-benefit & $\begin{array}{l}\text { Landscape } \\
\text { Animal and plant life }\end{array}$ & Urban development & & \\
\hline $\begin{array}{l}\text { (Portugal et al., } \\
\text { 2011) }\end{array}$ & $\begin{array}{l}\text { Location of intermodal } \\
\text { freight terminals }\end{array}$ & $\begin{array}{l}\text { Accessibility to main roads } \\
\text { Accessibility to cargo destinations } \\
\text { Incompatibility of truck and road, terminal } \\
\text { and neighborhood. } \\
\text { Inadequate loading and unloading }\end{array}$ & $\begin{array}{l}\text { Construction cost } \\
\text { Operation cost }\end{array}$ & Air pollution & & $\begin{array}{l}\text { Traffic safety } \\
\text { Terminal } \\
\text { security }\end{array}$ & \\
\hline $\begin{array}{l}\text { (Turcksin et al., } \\
\text { 2011) }\end{array}$ & $\begin{array}{l}\text { Policy to promote clean } \\
\text { passenger transport }\end{array}$ & $\begin{array}{l}\text { Km driven } \\
\text { Technical feasibility }\end{array}$ & Financial feasibility & $\begin{array}{l}\text { Fleet emissions }\left(\mathrm{CO}_{2}, \mathrm{NOx},\right. \\
\mathrm{PM}) \\
\text { Average Ecoscore }\end{array}$ & Sociopolitical acceptance & & \\
\hline
\end{tabular}




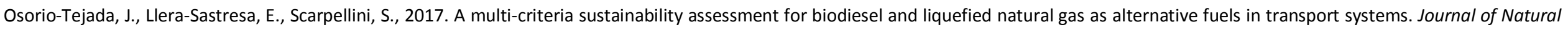
Gas Science and Engineering, 42, pp. 169-186. PRE-PRINT version of: $\underline{\mathrm{dx} . \text { doi.org/10.1016/i.jngse.2017.02.046 }}$

Table A. 1. (continued)

\begin{tabular}{|c|c|c|c|c|c|c|c|}
\hline \multirow{2}{*}{ Reference } & \multirow{2}{*}{ Scope of study } & \multicolumn{6}{|c|}{ Criteria } \\
\hline & & Technical/operational & Economic & Environmental & Social & Safety & Policy \\
\hline $\begin{array}{l}\text { (Duleba et al., } \\
\text { 2012) }\end{array}$ & $\begin{array}{l}\text { Analysis of users } \\
\text { preferences in urban } \\
\text { bus transport }\end{array}$ & $\begin{array}{l}\text { Approachability, directness, time } \\
\text { availability, Perspicuity, info before } \\
\text { travel, info during travel, speed, } \\
\text { reliability, Physical and mental comfort }\end{array}$ & & & & $\begin{array}{l}\text { Safety of } \\
\text { travel }\end{array}$ & \\
\hline $\begin{array}{l}\text { (Haddad and } \\
\text { Fawaz, 2012) }\end{array}$ & $\begin{array}{l}\text { Alternative fuels for } \\
\text { air transport }\end{array}$ & $\begin{array}{l}\text { Production capacity } \\
\text { Fuel readiness level } \\
\text { Compatibility }\end{array}$ & $\begin{array}{l}\text { Fuel cost } \\
\text { Capital cost } \\
\text { Operating cost }\end{array}$ & Impacts on water, air and land & & & \\
\hline $\begin{array}{l}\text { (Tsita and } \\
\text { Pilavachi, 2012) }\end{array}$ & $\begin{array}{l}\text { Alternative fuels for } \\
\text { road passenger } \\
\text { transport }\end{array}$ & Energy security & $\begin{array}{l}\text { Implementation cost, } \\
\text { technology maturity cost, } \\
\text { cost of energy }\end{array}$ & $\mathrm{CO}_{2}$ emissions & $\begin{array}{l}\text { Employment } \\
\text { Social welfare }\end{array}$ & & \\
\hline $\begin{array}{l}\text { (Zubaryeva et al., } \\
\text { 2012) }\end{array}$ & $\begin{array}{l}\text { Identifying potential } \\
\text { markets for electric } \\
\text { vehicles }\end{array}$ & $\begin{array}{l}\text { Car density (cars/100 inhabitants) } \\
\text { Commuting behavior } \\
\text { Infrastructure availability } \\
\text { Existing demo-projects }\end{array}$ & Fuel cost savings & $\begin{array}{l}\text { Average temperature } \\
\mathrm{CO}_{2} \text { emissions (fuel) } \\
\mathrm{CO}_{2} \text { emissions (car) } \\
\text { Energy use }\end{array}$ & & & $\begin{array}{l}\text { State } \\
\text { incentives }\end{array}$ \\
\hline (Jones et al., 2013) & $\begin{array}{l}\text { Road infrastructure } \\
\text { investment }\end{array}$ & $\begin{array}{l}\text { Accessibility } \\
\text { Reliability } \\
\text { Mental comfort }\end{array}$ & & $\begin{array}{l}\text { Air pollution } \\
\text { Noise }\end{array}$ & $\begin{array}{l}\text { Affordability } \\
\text { Provision to walk, cycle and } \\
\text { public transportation } \\
\text { Disruption of property }\end{array}$ & Safety & \\
\hline (Rossi et al., 2013) & $\begin{array}{l}\text { Policies for clean } \\
\text { passenger transport }\end{array}$ & & $\begin{array}{l}\text { Operating cost } \\
\text { User cost variation }\end{array}$ & $\begin{array}{l}\mathrm{CO}_{2} \text { and } \mathrm{CO} \text { emission } \\
\text { Noise } \\
\text { Fuel consumption }\end{array}$ & $\begin{array}{l}\text { Propensity towards service } \\
\text { Community livability }\end{array}$ & & \\
\hline $\begin{array}{l}\text { (Shiau and Liu, } \\
\text { 2013) }\end{array}$ & $\begin{array}{l}\text { Sustainable transport } \\
\text { solutions }\end{array}$ & $\begin{array}{l}\text { Model split, service intensity, loading } \\
\text { factor, parking lots ratio, bus lanes ratio, } \\
\text { modal split of non-motorized modes, } \\
\text { and the effect of public depot on freight } \\
\text { transshipment }\end{array}$ & & $\begin{array}{l}\text { GHG } \\
\text { Air pollutants } \\
\text { Proximity to sensitive areas } \\
\text { Energy use }\end{array}$ & $\begin{array}{l}\text { Mobility of older adults and } \\
\text { disable people } \\
\text { Transport subsidy in remote } \\
\text { areas }\end{array}$ & Accidents & \\
\hline $\begin{array}{l}\text { (Tsita and } \\
\text { Pilavachi, 2013) }\end{array}$ & $\begin{array}{l}\text { Alternative fuels for } \\
\text { road passenger } \\
\text { transport }\end{array}$ & $\begin{array}{l}\text { Technology maturity } \\
\text { Infrastructure availability } \\
\text { Energy security }\end{array}$ & $\begin{array}{l}\text { Production cost } \\
\text { Investment cost } \\
\text { Infrastructure cost }\end{array}$ & $\mathrm{CO}_{2}$ emissions & $\begin{array}{l}\text { Public acceptance } \\
\text { Food competition } \\
\text { Job creation }\end{array}$ & & \\
\hline $\begin{array}{l}\text { (Vermote et al., } \\
\text { 2013) }\end{array}$ & $\begin{array}{l}\text { Road networks for } \\
\text { freight transport }\end{array}$ & $\begin{array}{l}\text { Heavy freight infrastructure } \\
\text { Congestion } \\
\text { Local and supra local accessibility }\end{array}$ & $\begin{array}{l}\text { Implementation and } \\
\text { operational costs } \\
\text { Property value }\end{array}$ & $\begin{array}{l}\text { Noise and air pollutants } \\
\text { Impact on biodiversity } \\
\text { Barrier effects }\end{array}$ & $\begin{array}{l}\text { Traffic livability (vibration, } \\
\text { emissions and noise) }\end{array}$ & Accidents & \\
\hline (De Luca, 2014) & $\begin{array}{l}\text { Public passenger } \\
\text { transport solutions }\end{array}$ & $\begin{array}{l}\text { Comfort (congestion, travel time waiting } \\
\text { time, reliability, travel info system) }\end{array}$ & Monetary cost (ticket) & $\begin{array}{l}\text { Air pollution } \\
\text { Noise pollution } \\
\text { Visual impact }\end{array}$ & & Safety & \\
\hline $\begin{array}{l}\text { (Gardziejczyk and } \\
\text { Zabicki, 2014) }\end{array}$ & $\begin{array}{l}\text { Road alignment } \\
\text { variants }\end{array}$ & $\begin{array}{l}\text { Length of road } \\
\text { Road tortuosity }\end{array}$ & Construction costs & $\begin{array}{l}\text { Impact on conservation } \\
\text { protected areas and wildlife } \\
\text { corridors } \\
\text { Influence on landscape }\end{array}$ & $\begin{array}{l}\text { Residential buildings nearby } \\
\text { Buildings to be demolished } \\
\text { Number of plots for } \\
\text { compulsory purchase }\end{array}$ & & \\
\hline $\begin{array}{l}\text { (Gogas et al., } \\
\text { 2014) }\end{array}$ & $\begin{array}{l}\text { Location of freight } \\
\text { port terminals }\end{array}$ & $\begin{array}{l}\text { Geostrategic location } \\
\text { Level of service } \\
\text { Competitiveness }\end{array}$ & & & $\begin{array}{l}\text { Quality of life improvement } \\
\text { Socioeconomic development }\end{array}$ & $\begin{array}{l}\text { Safety and } \\
\text { security }\end{array}$ & \\
\hline
\end{tabular}




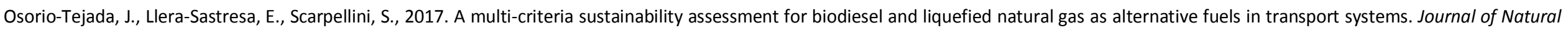
Gas Science and Engineering, 42, pp. 169-186. PRE-PRINT version of: $\underline{\mathrm{dx} . \mathrm{doi} . \mathrm{org} / 10.1016 / \mathrm{i} . j n g s e .2017 .02 .046}$

Table A. 1. (continued)

\begin{tabular}{|c|c|c|c|c|c|c|c|}
\hline \multirow{2}{*}{ Reference } & \multirow{2}{*}{ Scope of study } & \multicolumn{6}{|c|}{ Criteria } \\
\hline & & Technical/operational & Economic & Environmental & Social & Safety & Policy \\
\hline $\begin{array}{l}\text { (J. Javid et al., } \\
\text { 2014) }\end{array}$ & $\begin{array}{l}\text { Policies for clean } \\
\text { passenger transport }\end{array}$ & Traffic congestion & Investment cost & $\begin{array}{l}\text { Air pollution } \\
\text { Impact on natural habitats }\end{array}$ & & & \\
\hline $\begin{array}{l}\text { (Kengpol et al., } \\
\text { 2014) }\end{array}$ & $\begin{array}{l}\text { Multimodal routes for } \\
\text { freight transport }\end{array}$ & $\begin{array}{l}\text { Operational risks, Infrastructure and } \\
\text { equipment risks } \\
\text { Freight damaged risks } \\
\text { Transportation time }\end{array}$ & $\begin{array}{l}\text { Transportation costs } \\
\text { Macro risks }\end{array}$ & $\begin{array}{l}\text { Freight damaged risks (Climate } \\
\text { change, toxic waste and visual } \\
\text { landscape }\end{array}$ & & & $\begin{array}{l}\text { Political and } \\
\text { legislatorial } \\
\text { risks }\end{array}$ \\
\hline $\begin{array}{l}\text { (Nosal and Solecka, } \\
\text { 2014) }\end{array}$ & $\begin{array}{l}\text { Public passenger } \\
\text { transport solutions }\end{array}$ & $\begin{array}{l}\text { Travel time, journey standard, rolling } \\
\text { stock index, level of integration, } \\
\text { Reliability and availability of urban } \\
\text { public transport system }\end{array}$ & $\begin{array}{l}\text { Profitability of the urban } \\
\text { public transport system } \\
\text { Investment costs }\end{array}$ & Environmentally friendly & & $\begin{array}{l}\text { Safety of } \\
\text { journeys }\end{array}$ & \\
\hline (Verma et al., 2014) & $\begin{array}{l}\text { Policy to improve } \\
\text { passenger mobility }\end{array}$ & $\begin{array}{l}\text { Commuting (Vehicle } \mathrm{km} \text { travelled and } \\
\text { vehicle minutes travelled) }\end{array}$ & Transport Investment cost & $\begin{array}{l}\mathrm{CO}, \mathrm{NOx}, \mathrm{HC} \\
\text { Energy consumption }\end{array}$ & & & \\
\hline $\begin{array}{l}\text { (von Doderer and } \\
\text { Kleynhans, 2014) }\end{array}$ & $\begin{array}{l}\text { Resources for biofuel } \\
\text { production }\end{array}$ & & $\begin{array}{l}\text { Financial-economic } \\
\text { viability (IRR, capital cost) }\end{array}$ & $\begin{array}{l}\text { Acidification, eutrophication, } \\
\text { photochemical ozone creation, abiotic } \\
\text { depletion and global warming } \\
\text { potential }\end{array}$ & $\begin{array}{l}\text { Employment } \\
\text { creation potential }\end{array}$ & & \\
\hline $\begin{array}{l}\text { (Lanjewar et al., } \\
\text { 2015) }\end{array}$ & $\begin{array}{l}\text { Alternative fuels for } \\
\text { road passenger } \\
\text { transport }\end{array}$ & $\begin{array}{l}\text { Vehicle capability, road facility } \\
\text { Speed of traffic flow } \\
\text { Sense of comfort } \\
\text { Energy supply, refueling station distance } \\
\text { Number of vehicle options available }\end{array}$ & $\begin{array}{l}\text { Implementation and } \\
\text { maintenance costs } \\
\text { Industrial relationship } \\
\text { Fuel cost }\end{array}$ & $\begin{array}{l}\text { Global warming potential } \\
\text { Air and noise pollution } \\
\text { Non-renewable resource depletion } \\
\text { potential } \\
\text { Energy efficiency }\end{array}$ & & & \\
\hline $\begin{array}{l}\text { (Macharis et al., } \\
\text { 2015) }\end{array}$ & $\begin{array}{l}\text { Modal choice in } \\
\text { freight transport }\end{array}$ & $\begin{array}{l}\text { Transport time } \\
\text { Congestion time }\end{array}$ & Transport price & $\begin{array}{l}\mathrm{CO}_{2} \text { emissions } \\
\text { Noise }\end{array}$ & & Accident risk & \\
\hline $\begin{array}{l}\text { (Ren and Lützen, } \\
\text { 2015) }\end{array}$ & $\begin{array}{l}\text { Alternative fuels for } \\
\text { sea transport }\end{array}$ & Maturity & $\begin{array}{l}\text { Capital cost } \\
\text { Operation cost }\end{array}$ & $\begin{array}{l}\text { SOx, NOx, PM } \\
\text { GHG }\end{array}$ & Social acceptability & & $\begin{array}{l}\text { Government } \\
\text { support }\end{array}$ \\
\hline $\begin{array}{l}\text { (Buwana et al., } \\
\text { 2016) }\end{array}$ & $\begin{array}{l}\text { Passenger transport } \\
\text { solutions }\end{array}$ & $\begin{array}{l}\text { Accessibility } \\
\text { Mobility } \\
\text { Comfortability }\end{array}$ & Investment cost & $\begin{array}{l}\text { Land use, habitat protection, } \\
\text { pollution, noise, and energy use }\end{array}$ & & Safety & \\
\hline $\begin{array}{l}\text { (Curiel-Esparza et } \\
\text { al., 2016) }\end{array}$ & $\begin{array}{l}\text { Policy to improve } \\
\text { passenger mobility }\end{array}$ & $\begin{array}{l}\text { Travel time } \\
\text { Comfort }\end{array}$ & $\begin{array}{l}\text { Initial cost } \\
\text { Operation cost } \\
\text { Environmental cost } \\
\text { Travel cost } \\
\end{array}$ & $\begin{array}{l}\text { Pollution } \\
\text { Noise } \\
\text { Carbon footprint }\end{array}$ & Health & & \\
\hline
\end{tabular}


Osorio-Tejada, J., Llera, E., Scarpellini, S., 2017. A multi-criteria sustainability assessment for biodiesel and liquefied natural gas as alternative fuels in transport systems. Journal of Natural Gas Science and Engineering, 42, pp. 169186. PRE-PRINT version of: dx.doi.org/10.1016/j.jngse.2017.02.046

\section{Appendix B}

Values in Table B. 1 correspond to the indicators and their respective units established in Table 2.

Table B.1. Data for each indicator in the case study

\begin{tabular}{|c|c|c|c|c|c|c|c|c|c|}
\hline \multirow{2}{*}{ Sub-criteria } & \multicolumn{3}{|c|}{ Vehicles } & \multicolumn{3}{|c|}{ Infrastructure } & \multicolumn{3}{|c|}{ Fuels } \\
\hline & LNG & Diesel & HVO & LNG & Diesel & HVO & LNG & Diesel & HVO \\
\hline Initial and maintenance costs $^{a}$ & $100 \mathrm{~K},+10 \%$ & $70 \mathrm{~K}$ & $70 \mathrm{~K}$ & - & - & - & 26.21 & 39.34 & 35.20 \\
\hline Reliability ${ }^{\mathrm{b}}$ & $-10 \%$ & - & 0 & 19 & $>1000$ & 81 & Good & Good & Fair \\
\hline Legislation $^{\mathrm{c}}$ & Subsidies & None & None & Directive & none & none & Low tax & None & None \\
\hline GHG emissions $^{\mathrm{d}}$ & - & - & - & - & - & - & $1.1-1.2$ & $1-1.25$ & $1.15-1.43$ \\
\hline Air pollutants $(\mathrm{NOx}, \mathrm{PM})^{\mathrm{e}}$ & - & - & - & - & - & - & $0.2,0.0004$ & $0.4,0.006$ & $0.4,0.006$ \\
\hline Noise $^{f}$ & $-50 \%$ & - & 0 & 0 & - & 0 & - & - & - \\
\hline Employment $^{\mathrm{g}}$ & - & - & - & Good & Fair & Fair & Poor & Good & Fair \\
\hline Social benefits ${ }^{\mathrm{h}}$ & - & - & - & Good & Fair & Fair & Good & Poor & Fair \\
\hline Social acceptability ${ }^{i}$ & Good & Fair & Fair & Fair & Fair & Fair & Good & Poor & Fair \\
\hline
\end{tabular}

${ }^{a}$ Vehicles: (Chandler, 2004; DTTL, 2014) and interviews. Fuels: (DLR et al., 2014; DTTL, 2014; Rolande LCNG, 2015; Spanish Government, 2016a)

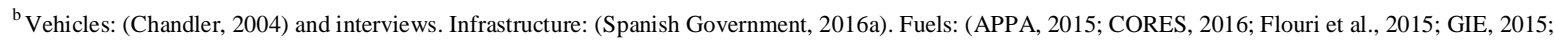
Hecking et al., 2015; Lochner, 2011; Richter and Holz, 2015)

${ }^{\mathrm{c}}$ Vehicles: (Fernandez, 2015; Mercedes-Benz España, 2009; Spanish Government, 2016b, 2015). Infrastructure: (European Parliament And The Council Of The European Union, 2014). Fuels: (European Commission, 2016)

${ }^{\mathrm{d}}$ Fuels: (ANL, 2014; DLR et al., 2014; Verbeek et al., 2015)

${ }^{\text {e}}$ Fuels: (Neste, 2016; Rolande LCNG, 2015; Verbeek et al., 2015)

${ }^{\mathrm{f}}$ Vehicles: (Mercedes-Benz España, 2009; Verbeek et al., 2015)

${ }^{\mathrm{g}}$ Infrastructure: (DTTL, 2014). Fuels: (DTTL, 2014; Ekener-Petersen et al., 2014; Manik et al., 2013)

${ }^{\text {h } I n f r a s t r u c t u r e: ~(D T T L, ~ 2014) . ~ F u e l s: ~(A P P A, ~ 2015 ; ~ C O R E S, ~ 2016 ; ~ D T T L, ~ 2014 ; ~ E b e g b u l e m ~ e t ~ a l ., ~ 2013 ; ~ E k e n e r-P e t e r s e n ~ e t ~ a l ., ~ 2014 ; ~ M a n i k ~ e t ~ a l ., ~ 2013 ; ~ M a r c o g a z, ~}$ 2008; Nwankwo, 2015; Omokaro, 2009)

${ }^{\text {i }}$ Vehicles, infrastructure and fuels: (DTTL, 2014) and own analyses based on semi-structured in-depth interviews to the different stakeholders

\section{Appendix C}

A pairwise comparison of the alternatives by sub-criterion is performed to obtain global priority vectors $\left(Y_{c f}\right)$ for each criterion and factor based on the Saaty AHP guidelines (Saaty, 1980):

a. For each sub-criterion, PCMs are performed to establish a rating of the relative importance among the alternatives considered. The rating is established from the following scale:

$1=$ equally preferred

$3=$ moderately preferred

$5=$ strongly preferred

$7=$ very strongly preferred

$9=$ extremely preferred

Pair values can be assigned as well as a reciprocal rating $(1 / 3,1 / 5 \ldots)$ when the second alternative is preferred over the first one. The number 1 is assigned to an alternative compared with itself.

b. Develop a normalized comparison matrix (NCM) by dividing each number into a column of the PCM by the sum of the column for each sub-criterion.

c. Develop the priority vector (PV) for each sub-criterion by calculating the average of each row of the NCM. This average per row vector represents the priority of the alternative with respect to the considered sub-criterion. 
Osorio-Tejada, J., Llera-Sastresa, E., Scarpellini, S., 2017. A multi-criteria sustainability assessment for biodiesel and liquefied natural gas as alternative fuels in transport systems. Journal of Natural Gas Science and Engineering, 42, pp. 169-186. PRE-PRINT version of: $\underline{\mathrm{dx} . \text { doi.org/10.1016/j.jngse.2017.02.046 }}$

d. The consistency of the ratings used in the PCM can be determined through the Consistency Ratio (CR) detailed in Saaty's literature. A CR of less than 0.10 is considered to be acceptable. When the CR is greater than 0.10, opinions and judgments should be reconsidered (Saaty and Vargas, 2001).

e. After completing the above points for each of the sub-criteria, the results obtained at point $c$ are summarized in a Priority Matrix (MP) by listing alternatives by row and sub-criteria by column.

f. Construction of the sub-criteria pairwise comparison matrix (SPCM) to obtain a sub-criteria priority vector (SPV) through the development of a NCM, which is similar to what was done for the alternatives comparison in points $a, b$ and $c$. The rating during the SPCM construction must be the same for the factors in the same criterion.

g. Develop global priority vectors $\left(Y_{c f}\right)$ of alternatives for each criterion and factor by multiplying the SPV obtained in the previous step by the MP of the alternatives from point $e$.

\section{References}

Akkermans, L., Leuven, M., 2014. GHG reduction measures for the Road Freight Transport sector.

Andrews, E.S., Barthel, L.-P., Tabea, B., Benoît, C., Ciroth, A., Cucuzzella, C., Gensch, C.-O., Hébert, J., Lesage, P., Manhart, A., Mazeau, P., 2009. Guidelines for Social Life Cycle Assessment of Products, Management. UNEP/SETAC Life Cycle Initiative.

ANL, 2014. The Greenhouse Gases, Regulated Emissions, and Energy Use in Transportation Model [WWW Document]. URL https://greet.es.anl.gov/ (accessed 5.20.15).

APPA, 2015. Asociacion de empresas de energias renovables [WWW Document]. Biocarburantes energía Renov. para una Movil. Sosten. en España. URL http://www.appa.es (accessed 9.28.16).

Awasthi, A., Chauhan, S.S., 2011. Using AHP and Dempster-Shafer theory for evaluating sustainable transport solutions. Environ. Model. Softw. 26, 787-796. doi:10.1016/j.envsoft.2010.11.010

Barfod, M.B., Salling, K.B., Leleur, S., 2011. Composite decision support by combining cost-benefit and multicriteria decision analysis. Decis. Support Syst. 51, 167-175. doi:10.1016/j.dss.2010.12.005

Benajes, J., Pastor, J. V., García, A., Monsalve-Serrano, J., 2015. The potential of RCCI concept to meet EURO VI NOx limitation and ultra-low soot emissions in a heavy-duty engine over the whole engine map. Fuel 159, 952-961. doi:10.1016/j.fuel.2015.07.064

Beria, P., Maltese, I., Mariotti, I., 2012. Multicriteria versus Cost Benefit Analysis: A comparative perspective in the assessment of sustainable mobility. Eur. Transp. Res. Rev. 4, 137-152. doi:10.1007/s12544-012-0074-9

Bhadury, J.., Khurana, S.., Peng, H.S.., Zong, H.., 2006. Optimization modeling in acquisitions: A case study from the motor carrier industry. J. Supply Chain Manag. 42, 41-54. doi:10.1111/j.1745-493X.2006.00021.x

Bilgen, S., Sarıkaya, İ., 2016. New horizon in energy: Shale gas. J. Nat. Gas Sci. Eng. 35, 637-645. doi:10.1016/j.jngse.2016.09.014

Blom, M., Solmar, C., 2009. How to Socially Assess Biofuels - A Case Study of the UNEP/SETAC Code of Practice for social- economical LCA. Luleå University of Technology, Stockholm.

Borrion, A.L., McManus, M.C., Hammond, G.P., 2012. Environmental life cycle assessment of lignocellulosic conversion to ethanol: A review. Renew. Sustain. Energy Rev. 16, 4638-4650. doi:10.1016/j.rser.2012.04.016

Buwana, E., Hasibuan, H.S., Abdini, C., 2016. Alternatives Selection for Sustainable Transportation System in Kasongan City. Procedia - Soc. Behav. Sci. 227, 11-18. doi:10.1016/j.sbspro.2016.06.037

Caliskan, N., 2006. A decision support approach for the evaluation of transport investment alternatives. Eur. J. Oper. Res. 175, 1696-1704. doi:10.1016/j.ejor.2005.02.035

Cambero, C., Sowlati, T., 2014. Assessment and optimization of forest biomass supply chains from economic, social and environmental perspectives - A review of literature. Renew. Sustain. Energy Rev. 36, 62-73. doi:10.1016/j.rser.2014.04.041

Carlson, A., 2011. Life cycle assessment of roads and pavements- Studies made in Europe, VTI rapport 736A. Swedish National Road and Transport Research Institute, Linköping.

Center for Sociological Research, 2016. Barómetro de julio 2016.

Chandler, K., 2004. Norcal prototype LNG truck fleet: Final Results.

CNH Industrial, 2014. 2014 Sustainability Report. 
Osorio-Tejada, J., Llera-Sastresa, E., Scarpellini, S., 2017. A multi-criteria sustainability assessment for biodiesel and liquefied natural gas as alternative fuels in transport systems. Journal of Natural Gas Science and Engineering, 42, pp. 169-186. PRE-PRINT version of: $\underline{\mathrm{dx} . \text { doi.org/10.1016/j.jngse.2017.02.046 }}$

CNMC, 2016. Comision nacional de los mercados y la competencia [WWW Document]. Estad. del Merc. hidrocarburos Liq. URL https://www.cnmc.es/es-es/energía/hidrocarburoslíquidos/biocarburantes.aspx (accessed 9.28.16).

Commission of the European Communities, 2001. WHITE PAPER. European policy for 2010: time to decide. Brussels.

CORES, 2016. Informe estadístico anual 2015, Informe estadistico anual 2015. doi:10.1017/CBO9781107415324.004

Curiel-Esparza, J., Mazario-Diez, J.L., Canto-Perello, J., Martin-Utrillas, M., 2016. Prioritization by consensus of enhancements for sustainable mobility in urban areas. Environ. Sci. Policy 55, 248-257. doi:10.1016/j.envsci.2015.10.015

De Luca, S., 2014. Public engagement in strategic transportation planning: An analytic hierarchy process based approach. Transp. Policy 33, 110-124. doi:10.1016/j.tranpol.2014.03.002

DENA, 2014. LNG in Germany : Liquefied Natural Gas and Renewable Methane in Heavy-Duty Road Transport. German Energy Agency, Aschersleben.

Deveci, M., Demirel, N. ??etin, John, R., ??zcan, E., 2015. Fuzzy multi-criteria decision making for carbon dioxide geological storage in Turkey. J. Nat. Gas Sci. Eng. 27, 692-705. doi:10.1016/j.jngse.2015.09.004

DLR, IFEU, LBST, DBFZ, 2014. LNG as an alternative fuel for the operation of ships and heavy-duty vehicles: Short study in the context of the National Mobility and Fuel Strategy. Munich.

Dodgson, J.S., Spackman, M., Pearman, A., Phillips, L.D., 2009. Multi-criteria analysis : a manual. London.

DTTL, 2014. Desarrollo del gas natural vehicular en España : análisis de beneficios y potencial contribución a la economía nacional.

Duleba, S., Mishina, T., Shimazaki, Y., 2012. A Dynamic Analysis on Public Bus Transport's Supply Quality by Using Ahp. Transport 27, 268-275. doi:10.3846/16484142.2012.719838

Dünnebeil, F., Lambrecht, U., 2012. Fuel efficiency and emissions of trucks in Germany - an overview.

Ebegbulem, J.C., Ekpe, D., Adejumo, T.O., 2013. Oil Exploration and Poverty in the Niger Delta Region of Nigeria: A Critical Analysis. Int. J. Bus. Soc. Sci. 4, 279-287.

EEGFTF, 2011. Report of the European Expert Group on Future Transport Fuels. Düsseldorf.

Ekener-Petersen, E., Höglund, J., Finnveden, G., 2014. Screening potential social impacts of fossil fuels and biofuels for vehicles. Energy Policy 73, 416-426. doi:10.1016/j.enpol.2014.05.034

Ekener, E., Hansson, J., Gustavsson, M., 2016. Addressing positive impacts in social LCA-discussing current and new approaches exemplified by the case of vehicle fuels. Int. J. Life Cycle Assess. 1-13. doi:10.1007/s11367-016-1058-0

Elghali, L., Cowell, S.J., Begg, K.G., Clift, R., 2006. Support for Sustainable Development Policy Decisions: A Case Study from Highway Maintenance. Int. J. Life Cycle Assess. 1, 29-39.

Elkington, J., 1998. Cannibals with Forks: the Triple Bottom Line of 21st Century Businesses. New Society Publishers, Gabriola Island, BC. doi:0865713928

Ellram, L.M., 1995. Total Cost of Ownership: An analysis approach for purchasing. Int. J. Logist. Manag. 6, 5566. doi:10.1108/09574099510805341

European Commission, 2016. Taxation and Customs Union [WWW Document]. Excise duty tables. URL http://ec.europa.eu/taxation_customs/index_en.htm (accessed 4.5.16).

European Commission, 2014. Eurostat Statistics Explained [WWW Document]. Freight Transp. Stat. - modal Split. URL http://ec.europa.eu/eurostat/statistics-explained/index.php/Freight_transport_statistics__modal_split (accessed 9.16.15).

European Commission, 2013. Clean Power for Transport: A European alternative fuels strategy. COM (2013) 17 final. Brussels.

European Commission, 2000. Green paper: Towards a European Strategy for the Security of Energy Supply. J. Med. Life 3, 430-2. doi:92-894-0319-5

European Environment Agency, 2015a. Greenhouse gas emissions from transport [WWW Document]. URL http://www.eea.europa.eu/data-and-maps/indicators/transport-emissions-of-greenhouse-gases/transportemissions-of-greenhouse-gases-5 (accessed 9.16.16).

European Environment Agency, 2015b. Annual European Union greenhouse gas inventory 1990 - 2013 and inventory report 2015. Copenhagen.

European Parliament And The Council Of The European Union, 2014. Directive 2014/94/EU on the deployment of alternative fuels infrastructure. Off. J. Eur. Union 57, 1-82.

European Parliament And The Council Of The European Union, 2009a. Regulation (EC) No 595/2009 on typeapproval of motor vehicles and engines with respect to emissions from heavy duty vehicles (Euro VI) and on access to vehicle repair and maintenance information and amending Regulation (EC) No 715/2007 and 
Osorio-Tejada, J., Llera-Sastresa, E., Scarpellini, S., 2017. A multi-criteria sustainability assessment for biodiesel and liquefied natural gas as alternative fuels in transport systems. Journal of Natural Gas Science and Engineering, 42, pp. 169-186. PRE-PRINT version of: $\underline{\mathrm{dx} . \text { doi.org/10.1016/j.jngse.2017.02.046 }}$

Directive 2007. Off. J. Eur. Union 1-13.

European Parliament And The Council Of The European Union, 2009b. Decision No. 406/2009/EC on the effort of Member States to reduce their greenhouse gas emissions to meet the Community's greenhouse gas emission reduction commitments up to 2020. Off. J. Eur. Union 136-148.

European Parliament And The Council Of The European Union, 2003. Directive 2003/87/EC establishing a scheme for greenhouse gas emission allowance trading within the Community and amending Council Directive 96/61/EC. Off. J. Eur. Communities 32-46.

Facanha, C., Horvath, A., 2007. Evaluation of life-cycle air emission factors of freight transportation. Environ. Sci. Technol. 41, 7138-7144. doi:10.1021/es070989q

Fargione, J., Hill, J., Tilman, D., Polasky, S., Hawthorne, P., 2008. Land clearing and the biofuel carbon debt. Science 319, 1235-8. doi:10.1126/science. 1152747

Fernandez, A., 2015. Gas natural vehicular [WWW Document]. Mercedes-Benz y Allison hacen posible una Distrib. urbana más limpia. URL http://www.gasvehicular.es/mercedes-benz-y-allison-hacen-posible-unadistribucion-urbana-mas-limpia/ (accessed 6.6.16).

Ferrari, P., 2003. A method for choosing from among alternative transportation projects. Eur. J. Oper. Res. 150, 194-203. doi:10.1016/S0377-2217(02)00463-0

Flouri, M., Karakosta, C., Kladouchou, C., Psarras, J., 2015. How does a natural gas supply interruption affect the EU gas security? A Monte Carlo simulation. Renew. Sustain. Energy Rev. 44, 785-796. doi:10.1016/j.rser.2014.12.029

Gardziejczyk, W., Zabicki, P., 2014. The influence of the scenario and assessment method on the choice of road alignment variants. Transp. Policy 36, 294-305. doi:10.1016/j.tranpol.2014.10.001

GASNAM, 2015. Estrategia de Impulso del vehículo con energías alternativas (VEA) en España (2014-2020). Propuesta y comentarios de GASNAM [WWW Document]. URL http://www.minetad.gob.es/industria/esES/Servicios/estrategia-impulso-vehiculo-energias-alternativas/JornadaJulio2015/presentacionGASNAM.pdf (accessed 3.15.17).

Gheewala, S.H., Damen, B., Shi, X., 2013. Biofuels: Economic, environmental and social benefits and costs for developing countries in Asia. Wiley Interdiscip. Rev. Clim. Chang. 4, 497-511. doi:10.1002/wcc.241

Gibbs, H.K., Johnston, M., Foley, J. a, Holloway, T., Monfreda, C., Ramankutty, N., Zaks, D., 2008. Carbon payback times for crop-based biofuel expansion in the tropics: the effects of changing yield and technology. Environ. Res. Lett. 3, 34001. doi:10.1088/1748-9326/3/3/034001

GIE, 2015. GIE LNG Map [WWW Document]. URL http://www.gie.eu/index.php/maps-data/lng-map (accessed 8.8.15).

Goedecke, M., 2005. Life Cycle Costs Analysis of Alternative Vehicles and Fuels in Thailand.

Gogas, M., Papoutsis, K., Nathanail, E., 2014. Optimization of Decision-Making in Port Logistics Terminals: Using Analytic Hierarchy Process for the Case of Port of Thessaloniki. Transp. Telecommun. J. 15, 255268. doi:10.2478/ttj-2014-0022

Goh, K.C., Yang, J., 2014. Managing cost implications for highway infrastructure sustainability. Int. J. Environ. Sci. Technol. 11, 2271-2280. doi:10.1007/s13762-014-0572-5

Hackney, J., de Neufville, R., 2001. Life cycle model of alternative fuel vehicles: emissions, energy, and cost trade-offs. Transp. Res. Part A-Policy Pract. 35, 243-266. doi:10.1016/S0965-8564(99)00057-9

Haddad, M., Fawaz, Z., 2012. Evaluation of microalgal alternative jet fuel using the AHP method with an emphasis on the environmental and economic criteria. Environ. Prog. Sustain. Energy 32, 721-733. doi:10.1002/ep. 11638

Hecking, H., John, C., Weiser, F., 2015. An Embargo of Russian Gas and Security of Supply in Europe. Zeitschrift für Energiewirtschaft 39, 63-73. doi:10.1007/s12398-014-0145-9

Heijungs, R., Huppes, G., Guinée, J.B., 2010. Life cycle assessment and sustainability analysis of products, materials and technologies. Toward a scientific framework for sustainability life cycle analysis. Polym. Degrad. Stab. 95, 422-428. doi:10.1016/j.polymdegradstab.2009.11.010

International organization for standardization, 2006. ISO 14040:2006. Environmental management — Life cycle assessment — Principles and framework, Iso 14040. doi:10.1136/bmj.332.7550.1107

J. Javid, R., Nejat, A., Hayhoe, K., 2014. Selection of CO2 mitigation strategies for road transportation in the United States using a multi-criteria approach. Renew. Sustain. Energy Rev. 38, 960-972. doi:10.1016/j.rser.2014.07.005

Jaffe, A.M., Dominguez-Faus, R., Lee, A., Medlock, K., Parker, N., Scheitrum, D., Burke, A., Zhao, H., Fan, Y., 2015. NextSTEPS White Paper: Exploring the Role of Natural Gas in U.S. Trucking [WWW Document]. URL http://steps.ucdavis.edu/files/02-18-2015-NextSTEPS-White-Paper-Natural-Gas-in-US-Trucking18Feb2015-Public-Release.pdf (accessed 3.13.15). 
Osorio-Tejada, J., Llera-Sastresa, E., Scarpellini, S., 2017. A multi-criteria sustainability assessment for biodiesel and liquefied natural gas as alternative fuels in transport systems. Journal of Natural Gas Science and Engineering, 42, pp. 169-186. PRE-PRINT version of: $\underline{\mathrm{dx} . \text { doi.org/10.1016/j.jngse.2017.02.046 }}$

Janic, M., 2007. Modelling the full costs of an intermodal and road freight transport network. Transp. Res. Part D Transp. Environ. 12, 33-44. doi:10.1016/j.trd.2006.10.004

Janic, M., Vleugel, J., 2012. Estimating potential reductions in externalities from rail-road substitution in TransEuropean freight transport corridors. Transp. Res. Part D Transp. Environ. 17, 154-160. doi:10.1016/j.trd.2011.09.015

Jones, S., Tefe, M., Appiah-Opoku, S., 2013. Proposed framework for sustainability screening of urban transport projects in developing countries: A case study of Accra, Ghana. Transp. Res. Part A Policy Pract. 49, 21-34. doi:10.1016/j.tra.2013.01.003

Kayikci, Y., 2010. A conceptual model for intermodal freight logistics centre location decisions. Procedia - Soc. Behav. Sci. 2, 6297-6311. doi:10.1016/j.sbspro.2010.04.039

Kengpol, A., Tuammee, S., Tuominen, M., 2014. The development of a framework for route selection in multimodal transportation. Int. J. Logist. Manag. 25, 581-610. doi:10.1108/IJLM-05-2013-0064

Kloepffer, W., 2008. Life Cycle Sustainability Assessment of Products (with Comments by Helias A. Udo de Haes, p. 95). Int. J. Life Cycle Assess. 13, 89-95. doi:http://dx.doi.org/10.1065/lca2008.02.376

Klungboonkrong, P., Taylor, M.A.P., 1998. A microcomputer-based system for multicriteria environmental impacts evaluation of urban road networks. Comput. Environ. Urban Syst. 22, 425-446. doi:10.1016/S01989715(98)00038-6

Krajnc, N., Domac, J., 2007. How to model different socio-economic and environmental aspects of biomass utilisation: Case study in selected regions in Slovenia and Croatia. Energy Policy 35, 6010-6020. doi:10.1016/j.enpol.2007.08.006

Lanjewar, P.B., Rao, R. V., Kale, A. V., 2015. Assessment of alternative fuels for transportation using a hybrid graph theory and analytic hierarchy process method. Fuel 154, 9-16. doi:10.1016/j.fuel.2015.03.062

Larson, E.D., 2006. A review of life-cycle analysis studies on liquid biofuel systems for the transport sector. Energy Sustain. Dev. 10, 109-126. doi:10.1016/S0973-0826(08)60536-0

Levine, J., Underwood, S.E., 1996. A multiattribute analysis of goals for Intelligent Transportation System planning. Transp. Res. Part C Emerg. Technol. 4, 97-111. doi:10.1016/0968-090X(96)00004-6

Li, H., Yang, S., Zhang, J., Kraslawski, A., Qian, Y., 2014. Analysis of rationality of coal-based synthetic natural gas (SNG) production in China. Energy Policy 71, 180-188. doi:10.1016/j.enpol.2014.04.018

Liu, K.F.R., Lai, J.-H., 2009. Decision-support for environmental impact assessment: A hybrid approach using fuzzy logic and fuzzy analytic network process. Expert Syst. Appl. 36, 5119-5136. doi:10.1016/j.eswa.2008.06.045

Lochner, S., 2011. Modeling the European natural gas market during the 2009 Russian-Ukrainian gas conflict: Ex-post simulation and analysis. J. Nat. Gas Sci. Eng. 3, 341-348. doi:10.1016/j.jngse.2011.01.003

Macharis, C., 2005. The importance of stakeholder analysis in freight transport: the MAMCA methodology. Eur. Transp. 25-26, 114-126.

Macharis, C., Meers, D., van Lier, T., 2015. Modal choice in freight transport: combining multi-criteria decision analysis and geographic information systems. Int. J. Multicriteria Decis. Mak. 5, 355-371. doi:10.1504/IJMCDM.2015.074087

Macharis, C., Verbeke, A., De Brucker, K., 2004. the Strategic Evaluation of New Technologies Through Multicriteria Analysis: the Advisors Case. Res. Transp. Econ. 8, 443-462. doi:10.1016/S07398859(04)08019-9

Malik, A., Lenzen, M., Geschke, A., 2016. Triple bottom line study of a lignocellulosic biofuel industry. GCB Bioenergy 8, 96-110. doi:10.1111/gcbb.12240

MAN SE, 2014. Corporate Responsibility at MAN 2014 - GRI Report.

Manik, Y., Halog, A., 2012. A Meta-Analytic Review of Life Cycle Assessment and Flow Analyses Studies of Palm Oil Biodiesel. Integr. Environ. Assess. Manag. 9, 134-141. doi:10.1002/ieam.2012-024OR.R1(1362)Notably

Manik, Y., Leahy, J., Halog, a, 2013. Social life cycle assessment of palm oil biodiesel: a case study in Jambi Province of Indonesia. Int. J. Life Cycle Assess. 18, 1386-1392. doi:10.1007/s11367-013-0581-5

Marcogaz, 2008. The Natural Gas Industry in Europe: key factors for a successful sustainable energy future [WWW Document]. MARCOGAZ Sustain. Rep. URL http://www.marcogaz.org/index.php/environmenthealth-a-safety (accessed 3.11.16).

Mercedes-Benz España, 2009. Mercedes-Benz entrega la primera tractora Econic GNL a Acotral [WWW Document]. URL http://www.mercedes.es/actualidad/noticias/news3.asp?NoNews=1718 (accessed 3.18.15).

Mohajeri, N., Amin, G.R., 2010. Railway station site selection using analytical hierarchy process and data envelopment analysis. Comput. Ind. Eng. 59, 107-114. doi:10.1016/j.cie.2010.03.006

Muench, S.T., 2010. Roadway Construction Sustainability Impacts. Transp. Res. Rec. J. Transp. Res. Board 2151, 
Osorio-Tejada, J., Llera-Sastresa, E., Scarpellini, S., 2017. A multi-criteria sustainability assessment for biodiesel and liquefied natural gas as alternative fuels in transport systems. Journal of Natural Gas Science and Engineering, 42, pp. 169-186. PRE-PRINT version of: $\underline{\mathrm{dx} . \text { doi.org/10.1016/j.jngse.2017.02.046 }}$

36-45. doi:10.3141/2151-05

Nahlik, M.J., Kaehr, A.T., Chester, M. V., Horvath, A., Taptich, M.N., 2016. Goods Movement Life Cycle Assessment for Greenhouse Gas Reduction Goals. J. Ind. Ecol. 20, 317-328. doi:10.1111/jiec.12277

Neste, 2016. Neste Renewable Diesel. Espoo.

Nosal, K., Solecka, K., 2014. Application of AHP method for multi-criteria evaluation of variants of the integration of Urban public transport. Transp. Res. Procedia 3, 269-278. doi:10.1016/j.trpro.2014.10.006

Nwankwo, B.O., 2015. The Politics of Conflict over Oil in the Niger Delta Region of Nigeria: A Review of the Corporate Social Responsibility Strategies of the Oil Companies. Am. J. Educ. Res. 3, 383-392. doi:10.12691/education-3-4-1

Omokaro, O., 2009. Oil and gas extraction in the Niger Delta region of Nigeria: The social and environmental challenges. FOG - Freib. Online Geosci. 24, 14-20.

Osorio-Tejada, J., Llera, E., Scarpellini, S., 2015. LNG : an alternative fuel for road freight transport in Europe, in: WIT Transactions on The Built Environment. Valencia, pp. 235-246. doi:10.2495/SD150211

Osorio-Tejada, J.L., Llera-Sastresa, E., Scarpellini, S., 2017. Liquefied natural gas: Could it be a reliable option for road freight transport in the EU? Renew. Sustain. Energy Rev. 71, 785-795. doi:10.1016/j.rser.2016.12.104

Päivinen, R., Lindner, M., Rosén, K., Lexer, M.J., 2012. A concept for assessing sustainability impacts of forestry-wood chains. Eur. J. For. Res. 131, 7-19. doi:10.1007/s10342-010-0446-4

Pereira, S., Seabra, J.E.A., 2013. Environmental benefits of the integrated production of ethanol and biodiesel. Appl. Energy 102, 5-12. doi:10.1016/j.apenergy.2012.09.016

Poh, K.L., Ang, B.W., 1999. Transportation fuels and policy for Singapore: An AHP planning approach. Comput. Ind. Eng. 37, 507-525. doi:10.1016/S0360-8352(00)00020-6

Pohekar, S.D., Ramachandran, M., 2004. Application of multi-criteria decision making to sustainable energy planning - A review. Renew. Sustain. Energy Rev. 8, 365-381. doi:10.1016/j.rser.2003.12.007

Portugal, L. da S., Morgado, A.V., Júnior, O.L., 2011. Location of cargo terminals in metropolitan areas of developing countries: the Brazilian case. J. Transp. Geogr. 19, 900-910. doi:10.1016/j.jtrangeo.2010.11.005

Quinn, J.C., Davis, R., 2015. The potentials and challenges of algae based biofuels: A review of the technoeconomic, life cycle, and resource assessment modeling. Bioresour. Technol. 184, 444-452. doi:10.1016/j.biortech.2014.10.075

Quintero, J.A., Montoya, M.I., Sánchez, O.J., Giraldo, O.H., Cardona, C.A., 2008. Fuel ethanol production from sugarcane and corn: Comparative analysis for a Colombian case. Energy 33, 385-399. doi:10.1016/j.energy.2007.10.001

Ren, J., Lützen, M., 2015. Fuzzy multi-criteria decision-making method for technology selection for emissions reduction from shipping under uncertainties. Transp. Res. Part D 40, 43-60. doi:10.1016/j.trd.2015.07.012

Richter, P.M., Holz, F., 2015. All quiet on the eastern front? Disruption scenarios of Russian natural gas supply to Europe. Energy Policy 80, 177-189. doi:10.1016/j.enpol.2015.01.024

Rolande LCNG, 2015. Battle of the trucks [WWW Document]. URL http://www.battleofthetrucks.nl/ (accessed 8.23.15).

Rossi, R., Gastaldi, M., Gecchele, G., 2013. Comparison of fuzzy-based and AHP methods in sustainability evaluation: A case of traffic pollution-reducing policies. Eur. Transp. Res. Rev. 5, 11-26. doi:10.1007/s12544-012-0086-5

Saaty, T., Vargas, L., 2001. Models, methods, concepts \& applications of the analytic hierarchy process, International Series in Operations Research \& Management Science. Springer Science+Business Media, New York.

Saaty, T.L., 1980. The Analytic Hierarchy Process, RWS Publications,Pittsburgh. McGraw-Hill, New York.

Sacchelli, S., Bernetti, I., De Meo, I., Fiori, L., Paletto, A., Zambelli, P., Ciolli, M., 2014. Matching socioeconomic and environmental efficiency of wood-residues energy chain: A partial equilibrium model for a case study in Alpine area. J. Clean. Prod. 66, 431-442. doi:10.1016/j.jclepro.2013.11.059

Scarpellini, S., Valero, A., Llera, E., Aranda, A., 2013. Multicriteria analysis for the assessment of energy innovations in the transport sector. Energy 57, 160-168. doi:10.1016/j.energy.2012.12.004

Schroeder, D.J., Majumdar, P., 2010. Feasibility analysis for solid oxide fuel cells as a power source for railroad road locomotives. Int. J. Hydrogen Energy 35, 11308-11314. doi:10.1016/j.ijhydene.2010.07.067

Shahraeeni, M., Ahmed, S., Malek, K., Van Drimmelen, B., Kjeang, E., 2015. Life cycle emissions and cost of transportation systems: Case study on diesel and natural gas for light duty trucks in municipal fleet operations. J. Nat. Gas Sci. Eng. 24, 26-34. doi:10.1016/j.jngse.2015.03.009

Shiau, T.A., Liu, J.S., 2013. Developing an indicator system for local governments to evaluate transport sustainability strategies. Ecol. Indic. 34, 361-371. doi:10.1016/j.ecolind.2013.06.001 
Osorio-Tejada, J., Llera-Sastresa, E., Scarpellini, S., 2017. A multi-criteria sustainability assessment for biodiesel and liquefied natural gas as alternative fuels in transport systems. Journal of Natural Gas Science and Engineering, 42, pp. 169-186. PRE-PRINT version of: $\underline{\mathrm{dx} . \text { doi.org/10.1016/j.jngse.2017.02.046 }}$

Shonnard, D.R., Klemetsrud, B., Sacramento-Rivero, J., Navarro-Pineda, F., Hilbert, J., Handler, R., Suppen, N., Donovan, R.P., 2015. A Review of Environmental Life Cycle Assessments of Liquid Transportation Biofuels in the Pan American Region. Environ. Manage. 56, 1356-1376. doi:10.1007/s00267-015-0543-8

Spanish Government, 2016a. Geoportal [WWW Document]. URL www.geoportalgasolineras.es (accessed 9.27.16).

Spanish Government, 2016b. Environmental labels. Official State Gazette Num 96, Sec. I. Page 26896. Spain.

Spanish Government, 2015. Real Decreto 1078/2015, de 27 de noviembre, por el que se regula la concesión directa de ayudas para la adquisición de vehículos de energías alternativas, y para la implantación de puntos de recarga de vehículos eléctricos en 2016, MOVEA. BOE, Spain.

Stickley, D.C., 2012. Expanding Best Practice: The Conundrum of Hydraulic Fracturing. Wyoming Law Rev. 12.

Streimikiene, D., Balezentis, T., Balezentiene, L., 2016. Comparative assessment of road transport technologies. Elsevier 56, 156-170.

Tsamboulas, D., Yiotis, G.., Panou, K., 1999. USE OF MULTICRITERIA METHODS FOR ASSESSMENT OF TRANSPORT PROJECTS. J. Transp. Eng. 125, 407-414. doi:10.1061/(ASCE)0733947X(1999) 125:5(407)

Tsita, K.G., Pilavachi, P.A., 2013. Evaluation of next generation biomass derived fuels for the transport sector. Energy Policy 62, 443-455. doi:10.1016/j.enpol.2013.07.114

Tsita, K.G., Pilavachi, P.A., 2012. Evaluation of alternative fuels for the Greek road transport sector using the analytic hierarchy process. Energy Policy 48, 677-686. doi:10.1016/j.enpol.2012.05.079

Tudela, A., Akiki, N., Cisternas, R., 2006. Comparing the output of cost benefit and multi-criteria analysis: An application to urban transport investment. Transp. Res. Part A Policy Pract. 40, 414-423. doi:10.1016/j.tra.2005.08.002

Turcksin, L., Bernardini, A., Macharis, C., 2011. A combined AHP-PROMETHEE approach for selecting the most appropriate policy scenario to stimulate a clean vehicle fleet. Procedia - Soc. Behav. Sci. 20, 954-965. doi:10.1016/j.sbspro.2011.08.104

Tuzkaya, U.R., 2009. Evaluating the environmental effects of transportation modes using an integrated methodology and an application. Int. J. Environ. Sci. Technol. 6, 277-290. doi:10.1007/BF03327632

Tzeng, G.H., Lin, C.W., Opricovic, S., 2005. Multi-criteria analysis of alternative-fuel buses for public transportation. Energy Policy 33, 1373-1383. doi:10.1016/j.enpol.2003.12.014

UNCED, U.N.C. on E. and D., 1992. United Nations Sustainable Development, Rio de Janeiro, Brazil, 3 to 14 June 1992. Agenda 21, Reproduction. doi:10.1007/s11671-008-9208-3

UNFCCC, 1998. Kyoto Protocol to the United Nations Framework Convention on Climate Change, United Nations Framework Convention on Climate Change. New York.

Uson, A.A., Capilla, A.V., Bribian, I.Z., Scarpellini, S., Sastresa, E.L., 2011. Energy efficiency in transport and mobility from an eco-efficiency viewpoint. Energy 36, 1916-1923. doi:10.1016/j.energy.2010.05.002

Verbeek, R., Verbeek, M., Energie, S., Nederland, D., 2015. LNG for trucks and ships : fact analysis Review of pollutant and GHG emissions Final. Delft.

Verma, A., Rahul, T.M., Dixit, M., 2014. Sustainability impact assessment of transportation policies - A case study for Bangalore city. Case Stud. Transp. Policy 3, 321-330. doi:10.1016/j.cstp.2014.06.001

Vermote, L., Macharis, C., Putman, K., 2013. A road network for freight transport in flanders: Multi-actor multicriteria assessment of alternative ring ways. Sustain. 5, 4222-4246. doi:10.3390/su5104222

Vijay, V., Pimm, S.L., Jenkins, C.N., Smith, S.J., 2016. The Impacts of Oil Palm on Recent Deforestation and Biodiversity Loss. PLoS One 11, e0159668. doi:10.1371/journal.pone.0159668

Volvo AB, 2013. Life cycle assessment [WWW Document]. Volvo Gr. Sustain. Rep. URL http://www3.volvo.com/investors/finrep/sr13/en/earningtrust/managingourvaluecha/productdevelopment/life cycleassessment/life-cycle-assessme.html (accessed 12.10.15).

von Blottnitz, H., Curran, M.A., 2007. A review of assessments conducted on bio-ethanol as a transportation fuel from a net energy, greenhouse gas, and environmental life cycle perspective. J. Clean. Prod. 15, 607-619. doi:10.1016/j.jclepro.2006.03.002

von Doderer, C.C.C., Kleynhans, T.E., 2014. Determining the most sustainable lignocellulosic bioenergy system following a case study approach. Biomass and Bioenergy 70, 273-286. doi:10.1016/j.biombioe.2014.08.014

VTT, 2011. Existing methods and tools for calculation of carbon footprint of transport and logistics. COFRET Deliverable 2.1.

Wang, J., Yang, Y., Sui, J., Jin, H., 2016. Multi-objective energy planning for regional natural gas distributed energy: A case study. J. Nat. Gas Sci. Eng. 28, 418-433. doi:10.1016/j.jngse.2015.12.008

Wang, J.J., Jing, Y.Y., Zhang, C.F., Zhao, J.H., 2009. Review on multi-criteria decision analysis aid in sustainable energy decision-making. Renew. Sustain. Energy Rev. 13, 2263-2278. doi:10.1016/j.rser.2009.06.021 
Osorio-Tejada, J., Llera-Sastresa, E., Scarpellini, S., 2017. A multi-criteria sustainability assessment for biodiesel and liquefied natural gas as alternative fuels in transport systems. Journal of Natural Gas Science and Engineering, 42, pp. 169-186. PRE-PRINT version of: $\underline{\mathrm{dx} . \text { doi.org/10.1016/j.jngse.2017.02.046 }}$

Weidema, B.P., 2006. The integration of economic and social aspects in life cycle impact assessment. Int. J. Life Cycle Assess. 11, 89-96. doi:10.1065/lca2006.04.016

Werhahn-Mees, W., Palosuo, T., Garcia-Gonzalo, J., R??ser, D., Lindner, M., 2011. Sustainability impact assessment of increasing resource use intensity in forest bioenergy production chains. GCB Bioenergy 3 , 91-106. doi:10.1111/j.1757-1707.2010.01068.x

Wicke, B., Dornburg, V., Junginger, M., Faaij, A., 2008. Different palm oil production systems for energy purposes and their greenhouse gas implications. Biomass and Bioenergy 32, 1322-1337. doi:10.1016/j.biombioe.2008.04.001

Wiloso, E.I., Heijungs, R., De Snoo, G.R., 2012. LCA of second generation bioethanol: A review and some issues to be resolved for good LCA practice. Renew. Sustain. Energy Rev. 16, 5295-5308. doi:10.1016/j.rser.2012.04.035

Yedla, S., Shrestha, R.., 2003. Multi-criteria approach for the selection of alternative options for environmentally sustainable transport system in Delhi. Transp. Res. Part A Policy Pract. 37, 717-729. doi:10.1016/S09658564(03)00027-2

Yeh, S., 2007. An empirical analysis on the adoption of alternative fuel vehicles: The case of natural gas vehicles. Energy Policy 35, 5865-5875. doi:10.1016/j.enpol.2007.06.012

You, F., Tao, L., Graziano, D.J., Snyder, S.W., 2012. Optimal design of sustainable cellulosic biofuel supply chains: Multiobjective optimization coupled with life cycle assessment and input-output analysis. AIChE J. 58, 1157-1180. doi:10.1002/aic.12637

Zhou, Z., Jiang, H., Qin, L., 2007. Life cycle sustainability assessment of fuels. Fuel 86, 256-263. doi:10.1016/j.fuel.2006.06.004

Zubaryeva, A., Thiel, C., Barbone, E., Mercier, A., 2012. Assessing factors for the identification of potential lead markets for electrified vehicles in Europe: Expert opinion elicitation. Technol. Forecast. Soc. Change 79, 1622-1637. doi:10.1016/j.techfore.2012.06.004 